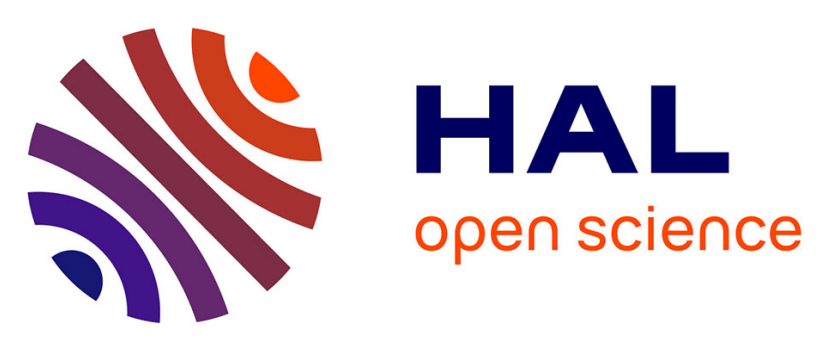

\title{
Clay mineral distributions in and around the Mississippi River watershed and Northern Gulf of Mexico: sources and transport patterns
}

T Sionneau, Viviane Bout-roumazeilles, P E Biscaye, B van Vliet-Lanoe, A Bory

\section{To cite this version:}

T Sionneau, Viviane Bout-roumazeilles, P E Biscaye, B van Vliet-Lanoe, A Bory. Clay mineral distributions in and around the Mississippi River watershed and Northern Gulf of Mexico: sources and transport patterns. Quaternary Science Reviews, 2008, 27 (17-18), pp.1740-1751. hal-03290439

\section{HAL Id: hal-03290439 \\ https://hal.science/hal-03290439}

Submitted on 19 Jul 2021

HAL is a multi-disciplinary open access archive for the deposit and dissemination of scientific research documents, whether they are published or not. The documents may come from teaching and research institutions in France or abroad, or from public or private research centers.
L'archive ouverte pluridisciplinaire HAL, est destinée au dépôt et à la diffusion de documents scientifiques de niveau recherche, publiés ou non, émanant des établissements d'enseignement et de recherche français ou étrangers, des laboratoires publics ou privés. 
1 Clay mineral distributions in and around the Mississippi River watershed and Northern Gulf of Mexico: sources and transport patterns

3

T. Sionneau ${ }^{\mathrm{a},{ }^{*}}$, V. Bout-Roumazeilles ${ }^{\text {a }}$, P.E. Biscaye ${ }^{\mathrm{b}}$, B. Van Vliet-Lanoe ${ }^{\mathrm{c}}$, A. Bory $^{\mathrm{a}, \mathrm{b}}$

a UMR CNRS 8157 “Géosystèmes”, Université de Lille 1, Bât. SN5, Cité Scientifique, 59655 Villeneuve d'Ascq Cedex, France

${ }^{\mathrm{b}}$ Lamont-Doherty Earth Observatory of Columbia University, Palisades, NY 10964, USA

${ }^{\mathrm{c}}$ UMR 6538 CNRS, Domaines Océaniques, IUEM, 29280 Plouzané, France

*Corresponding author. Tel.: +33 3204370 38; fax: +33 3204349 10. E-mail address: thomas.sionneau@ed.univ-lille1.fr (T. Sionneau).

\section{Abstract}

Maps of the distributions of the four major clay minerals (smectite, illite, kaolinite and chlorite) in and around the Mississippi River drainage basin and in the Northern Gulf of Mexico have been produced using newly acquired data from erodible/alluvial terrestrial sediments and marine surface sediments, as well as from previously published data. East of the Rockies, North America can be divided into four, large, clay-mineral provinces: (1) the north-western Mississippi River watershed (smectite rich), (2) the Great Lakes area and eastern Mississippi River watershed (illite and chlorite rich), (3) the south-eastern United States (kaolinite rich) and (4) the Brazos River and south-western Mississippi River watersheds (illite and kaolinite rich). The clay mineral distributions in surface sediments of the present-day Gulf of Mexico are strongly influenced by three main factors: (1) by relative fluvial contributions: the Mississippi River delivers the bulk of the clay input to the Northern Gulf of Mexico whereas the Apalachicola, Mobile, Brazos and Rio Grande rivers inputs have more local influences; (2) by differential settling of various clay mineral species, which is identified for the first time in Northern Gulf of Mexico sediments; and (3) by oceanic current transport: the Gulf of Mexico surface and subsurface circulation distributes the clay-rich sediments from river mouth sources throughout the Northern Gulf of Mexico.

\section{Introduction}

Clay minerals are a dominant component of most marine sediments, and are mainly land-derived (Biscaye, 1965; Griffin et al., 1968). Their geographic distributions and sources 
have been extensively investigated since the 1960s (Biscaye, 1965; Griffin and 35 Goldberg,1969; Rateev et al.,1969; Gradusov,1974; Windom,1976). Studies of clay mineral assemblages provide information on climatic conditions, such as precipitation and runoff patterns over the adjacent continents (Chamley,1989), as well as on the dynamics of river inputs (Pinsak and Murray, 1960; Scafe and Kunze, 1971; Doyle and Sparks, 1980). Clay minerals can be advected over long distances and then settle far away from their source area, especially if being re-transported in the nepheloid layer (Biscaye and Eittreim, 1977; Jones, 1984). Thus, clay mineral assemblages have also been successfully used to trace oceanic current patterns (Petschick et al., 1996; Fagel et al., 1997; Gingele et al., 2001; Boulay et al., 2005).

The Gulf of Mexico has been an important area for global thermohaline circulation and for the global climatic system (Broecker, 1991) especially since the closure of the Isthmus of Panama 4.6 million years ago (Haug and Tiedemann, 1998). Gulf of Mexico surface waters are characterized by high temperature and high salinity that further influence the Gulf Streamwater properties. The hydrological features of the Gulf of Mexico were strongly modified by the inputs of freshwater resulting from melting pulses of the Laurentide Ice Sheet (LIS) during the last glacial cycle and the last deglaciation (Kennett and Shackleton, 1975; Leventer et al., 1982; Joyce et al., 1993; Aharon, 2003; Flower et al., 2004). Changes of salinity resulting from these melting pulses are thought to have altered the thermohaline circulation, the global heat exchange and worldwide climatic conditions (Broecker et al., 1990; Bond, 1995; Rahmstorf, 1995; Manabe and Stouffer, 1997). Although the direct palaeoceanographic effects of these freshwater supplies on the Gulf of Mexico have been studied largely using d180 variations, the associated terrigenous inputs (mostly clay minerals; Brown and Kennett, 1998) have been poorly investigated. They may, however, provide information on the varying continental provenance of these freshwater pulses and therefore help close the gap between climate variations over the continent (e.g. the dynamics of the LIS/ proglacial lake overflows and/or increase in precipitation; Broecker et al., 1989; Teller, 1995; Clark et al., 2001; Clarke et al., 2003) and the hydrological changes in the Gulf of Mexico. In order to use clay mineral records from the Gulf of Mexico for palaeoclimate reconstructions (Sionneau et al., in preparation), one must have a good knowledge of clay mineral continental sources and of the factors influencing their distribution in the Gulf of Mexico. It seems reasonable to assume that the nature of the main clay mineral provinces in North America has remained unchanged during the late Quaternary. Variations in clay 
changes in erosion and transport pattern, even if their intrinsic nature derived from weathering processes developed over longer timescale (Thiry et al., 1999; Thiry, 2000).

The present Gulf of Mexico circulation pattern is relatively well known (Fig. 1). Its sedimentology has been extensively studied (Griffin, 1962; Doyle and Sparks, 1980; Balsam and Beeson, 2003; Ellwood et al., 2006). None of these studies, however, combined data from both continental and marine environments, and no overall clay mineral distributions over North America and the Northern Gulf of Mexico are available today.

In this paper, we present the clay mineral assemblage of 28 continental sites [consisting of 85 new samples and data from Griffin (1962) and Potter et al. (1975)] over North America and of 67 core-top samples collected over the Northern Gulf of Mexico. The main objectives of this study are: (1) to map clay mineral distributions over both the North American continent east of the Rockies and the Northern Gulf of Mexico; (2) to discern and distinguish the continental sources of the principal marine clay minerals; and (3) to identify the main parameters (fluvial contributions, differential settling, oceanic currents) controlling the present-day marine distribution of these clay minerals in the Northern Gulf of Mexico.

\section{Samples}

Marine core-top samples were recovered during the RVs Robert Conrad (RC), Vema (VM) and Atlantis (AT) cruises (Lamont core collection; Table 1; samples 13-67) as well as during the RV Marion Dufresne IMAGES cruise PAGE in 2002 (Bout-Roumazeilles and Trentesaux, 2006; samples 3-12) and PICASSO in 2003 (Laj et al., 2004; samples 1 and 2). They are broadly distributed over the northern Gulf of Mexico (Fig. 2) and are located within the different geomorphologic provinces that characterize this area (Fig. 3).

Over the North American continent, 85 samples were collected from different types of sediment (loess, recent mineral dust deposits, tills, lake and river) at 14 sites (Fig. 4, Table 2). Sediment samples of fluvial origin were taken from the $\mathrm{C}$ horizon of alluvial plain soils (about 1.5-2 $\mathrm{m}$ depth) from which, except for the carbonate content, the mineralogical composition is not likely to have been disturbed by anthropogenic activity and should reflect the bulk composition of superficial deposits such as loess, alluvium or tills (Gallet et al., 1998). All these continental samples are commonly representative of the regional and/or upstream watershed average mineralogical composition. In addition we have included published clay mineral data from 11 sites on the Mississippi river system (Potter et al., 1975) and from the Mobile Embayment, the Mississippi and the Apalachicola River mouths (Fig. 5, Table 2; Griffin, 1962). The majority of the continental sites (20 of 28) are located in the 
present-day Mississippi River watershed (Fig. 4).

\section{Methods}

X-ray diffraction analyses (XRD) were performed at the University of Lille and the LDEO (Lamont-Doherty Earth Observatory of Columbia University). In this paper, "clay minerals" refer to the major phyllocilicate minerals within the clay-size fraction (generally $<2 \mathrm{~mm}$ ). They are identified by XRD following the protocol of Holtzapffel (1985). All samples were first decalcified with $0.2 \mathrm{~N} \mathrm{HCl}$. The excess acid was removed by repeated washings with distilled water and centrifugations. The clay-size fraction was separated by settling according to Stokes's law, concentrated by centrifugation, and oriented by wet smearing on glass slides. The analyses were run on a Philips PW 1749 generator (copper anode; $40 \mathrm{kV}$ voltage; $25 \mathrm{~mA}$ intensity and $1^{\circ} 2 \mathrm{q} / \mathrm{min}$ speed) at the University of Lille, and on

114 a Philips X'Pert-MPD (q-q goniometer; $\mathrm{Cu}$ X-ray tube; Peltier-cooled, high sensitivity, 115 Kevex energy dispersive detector) at the LDEO. A complete X-ray diffraction analysis requires several runs to permit precise mineral identification. Two XRD runs were performed routinely for each sample: (1) air-dried sample ("normal” run) and (2) ethylene-glycol vapour saturation for $12 \mathrm{~h}$ ("glycol" run). The analyses were run from $2.49^{\circ}$ to $32.49^{\circ} 2 \theta$. Each clay mineral is characterized by its basal layer plus interlayer interval (d) as revealed by XRD analysis (Brown and Brindley, 1980). Smectite (" $\mathrm{S}$ ') is characterized by a peak at $14 \AA$ on the normal run, which expands to $17 \AA$ after saturation by ethylene glycol. Illite (" I'") presents a basal peak at $10 \AA$ on the two runs. Chlorite (" $\mathrm{C}$ ") is characterized by peaks at 14 $\AA$ (001), $7 \AA$ (002), $4.75 \AA$ (003) and $3.53 \AA$ (004) on the two diffraction spectra. Kaolinite (' $\mathrm{K}$ ') is characterized by peaks at $7 \AA(001)$ and $3.58 \AA(002)$ on the normal and glycol runs. To distinguish kaolinite from chlorite, the portion of the spectrum containing the basal peaks of kaolinite (002) and chlorite (004) around $3.55 \AA$ is step-scanned in a high-resolution mode following standard procedures described in detail by Petschick et al. (1996). Semiquantitative estimation of clay mineral abundances is based on peak areas, weighted by empirically estimated factors (Biscaye, 1965; Biscaye et al., 1997) and summed to $100 \%$ (S + $\mathrm{I}+\mathrm{K}+\mathrm{C}=100 \%)$. Peak area measurements were realized in the glycol runs using the

131 Macintosh Mac- Diff ${ }^{\circledR}$ 4.2.5 software (Petschick, 2000). Results are given in Tables 1 and 2.

132 The error on the reproducibility of measurements is estimated to be $\pm 5 \%$ for each clay 133 mineral. The mixed-layered clay minerals identified by Potter et al. (1975) in Ohio River and

134 Tennessee River samples (sites 14 and 15) were not taken into account in the percentages 135 since their exact nature (vermiculite and/or illite-chlorite and/or illite-smectite) is unknown. 
136 All data were recalculated according to the $\mathrm{S}+\mathrm{I}+\mathrm{K}+\mathrm{C}=100 \%$ formula in order to be compared to each other. The data have been gridded and contoured using the Surfer ${ }^{\circledR} 8$ software. For each clay mineral, scales between isolines of land and sea maps are different to allow a better representation of their relative variations in each environment. Map contours do not represent precise boundaries of clay mineral composition on land, but rather indicate rough limits between the dominant source areas of each clay mineral over the United States, based on our dataset.

\section{Clay mineral distribution}

In most continental environments, illite and chlorite are usually inherited from ancient rocks (Palaeozoic, pre-Cambrian) modified by physical or moderate chemical weathering at high latitudes or altitude where Quaternary periglacial climatic conditions prevail. In North America, kaolinite forms through long-term weathering processes during preglacial time (Thiry et al., 1999; Thiry, 2000). It can derive from saprolites as well as from old sedimentary formations and may also form in solfatares in association with smectite (Huertas et al., 1999). Smectite is either derived from volcanic ash layers or authigenic in poorly-drained environments as in alluvial or coastal plains (Kraus, 1999; synthesis in Gerrard et al., 2007). Smectite can also be locally formed in the marine environment through early diagenesis, halmyrolysis (Karpoff et al., 1989), or hydrothermal weathering of volcanic rocks (Chamley, 1998).

\subsection{Clay mineral distributions in and around the Mississippi River watershed}

Three large areas can be distinguished based on smectite abundance patterns (Fig. 6a). The first covers a huge part of the Mississippi River watershed, including the Missouri River basin and Mississippi River alluvial plains. A corridor of high smectite values $(>40 \%)$ extends from Saskatchewan to the Mississippi River mouth and separates two areas of low smectite content $(<20 \%)$ : the eastern Mississippi River and the north-western Texas watersheds. Smectite decreases rapidly (from $45 \%$ to $0 \%$ in few hundreds of kilometres) from the Mississippi River toward the eastern part of the United States of America (USA).

Due to the calculation method used, clay mineral percentages are not independent of each other. Because clay minerals are summed to $100 \%$, variations in the two most abundant ones (smectite and illite) have opposite trends. Two major zones characterized by high illite concentrations can be observed in the distribution pattern of that mineral (Fig. 6b). Sediments 
areas northeast and southwest of Lake Huron. Similarly the clay mineral fraction of sediments from north-western Texas (Gulf Coast Rivers of the south-western USA and southwestern Mississippi River watersheds) contain more than $40 \%$ illite. Those two zones are separated by an illite depletion extending from the north-western Mississippi River basin to the southeastern USA. This zone is composed of three minimal areas $(<15 \%)$ : Saskatchewan, the lower Arkansas River and Alabama-Florida coastal plains between the Mobile Embayment and the Apalachicola River mouth.

The south-eastern USA where soils and sediments are very rich in kaolinite $(>30 \%)$ is one of the most important sources of this mineral. Kaolinite proportions are maximal in north Florida, exceeding 60\% (Fig. 7a). Two other potential source areas for kaolinite, characterized by values around 20\%, are located in the upper Mississippi River and around the Pecos River in Texas. The Missouri River system and the middle and lower Mississippi River alluvial plain sediments display low kaolinite content, contrasting with the high values to the west and to the east.

The chlorite distribution displays an East-West decreasing gradient (Fig. 7b). High values of chlorite $(>20 \%)$ are found in the eastern part of the USA (east of about $087^{\circ} \mathrm{W}$ ). Chlorite abundance decreases westward, first sharply down to about $10 \%$, in the Mississippi River valley, and then more gradually, down to $<4 \%$, toward the Gulf of Mexico coastal plains, the western Mississippi River watershed and north-western Texas.

Since in most continental environments, smectite and kaolinite are generally formed by chemical weathering, while illite and chlorite are mostly inherited from ancient rocks modified by physical or moderate chemical weathering, the clay mineral ratio $($ smectite + kaolinite $) /($ illite + chlorite) indicates the type of weathering (chemical or physical) that affected the erodible sediments. According to the distribution of this $(S+K) /(I+C)$ ratio (Fig. 8), the North American continent east of the Rockies can be divided in different dominant weathering-regime areas.

The south-eastern United States is characterized by maximum values of the ratio $(>4)$, suggesting that chemical weathering prevails in this region. This seems to be in agreement with the presence of yellow-red subtropical soils (Fig. 5). The important hydrolysis results from both high precipitation $\left(>1000 \mathrm{~mm} /\right.$ year) and high temperatures $\left(>5{ }^{\circ} \mathrm{C}\right.$ in winter and $>25{ }^{\circ} \mathrm{C}$ in summer) that characterize this region. The north-eastern United States as well as the south-western Mississippi River watershed display minimum values of the $(\mathrm{S}+\mathrm{K}) /(\mathrm{I}+\mathrm{C})$ ratio $(<1)$. As expected from local climatic conditions and altitude, these areas seem to be dominated by physical weathering processes. The respective contributions of both physical 
and chemical weathering can not be easily deduced in the other areas characterized by intermediate values of the $(\mathrm{S}+\mathrm{K}) /(\mathrm{I}+\mathrm{C})$ ratio.

\subsection{Distribution in the northern Gulf of Mexico}

The clay mineral distribution maps of the Gulf of Mexico cover various geomorphologic provinces including the Texas slope, the Louisiana shelf and continental slope, the Mississippi River delta, the Alabama shelf, the Florida shelf and the deep-sea plain (Figs. 3, 6 and 7).

Smectite is the dominant clay mineral and represents more than $50 \%$ of the clay mineral fraction in surface sediments from the central and western parts of the Northern Gulf of Mexico (Table 1, Fig. 6a). The smectite content is lower on the Alabama and Florida shelves with values below 40\%. The illite content ranges between $13 \%$ and $40 \%$ (Fig. 6b). Overall, the illite abundance decreases from the northern Gulf of Mexico continental shelves toward the deep-sea plain. This decreasing trend is particularly clear from the proximal to the distal parts of the Mississippi River Delta. Nevertheless, an illite-rich area extends from the Louisiana coasts to the deep-sea plain and constitutes an exception in the illite general trend. The distribution of kaolinite displays an overall West-East increasing gradient in the Gulf of Mexico (Fig. 7a). Kaolinite percentages are minimal $(<20 \%)$ on the central and western parts of the northern Gulf of Mexico. They increase eastward and reach heir maximum ( $>24 \%)$ on the Florida shelf. Chlorite is the least abundant clay mineral in the Gulf of Mexico, ranging from $0 \%$ to $20 \%$ (Fig. $6 \mathrm{~b}$ ). The chlorite content is minimal in the areas located off the Mississippi River mouth and in the Louisiana shelf $(<4 \%)$, and maximum in the eastern and southern parts of the Northern Gulf of Mexico.

\section{Main clay mineral provinces of the United States of America east of the Rocky}

\section{Mountains}

The United States east of the Rockies can be subdivided in four major mineralogical provinces (Fig. 9) based on the distribution maps of the main clay minerals (Fig. 6 and 7).

(Zone 1) The western part of the Mississippi River watershed including the entire Missouri River system, is defined by high smectite content ( $>40 \%$; Fig. 6a). The relative abundance of smectite reflects the mineralogy of the Great Plains soils (Allen et al., 1972; Smith, 2003). Early studies (Murray and Leininger, 1956; Pinsak and Murray, 1960) noticed that the Missouri River carries large amounts of smectite of bentonitic origin. Smectite in the 
238 Canadian prairie soils (Curtin et al., 1998). Part of the smectite may also be authigenic and

239 form in poorly drained soils, from the main Mississippi River valley or from the surrounding periglacial loess (Fig. 5; Pye and Johnson, 1988). Illite is less abundant, ranging from $10 \%$ to $30 \%$ (Fig. 6b). In this province, an increase of illite in the detrital loads of rivers is observed after winter, when illite, formed through glaciogenic processes, by physical weathering and erosion of parent rocks, is easily removed by rainfall/meltwater and then exported towards the ocean via rivers (Weaver, 1967). The eastern part of this area (Wisconsin), in the Upper Mississippi River catchment basin between Lakes Superior and Michigan is characterized by locally higher kaolinite content $(>20 \%$; Fig. 7a). Kaolinite is derived commonly from a saprolite developed during the Mesozoic and early Tertiary on Precambrian basement, particularly in the area of River Falls (site 8 in Fig. 4; Irving, 1876; Cummings and Scrivner, 249 1980).

(Zone 2) The region composed by the Great Lakes area and the eastern Mississippi River watershed is characterized mainly by illite ( $>25 \%$; Fig. $6 \mathrm{~b})$ and chlorite-rich sediments ( $>20 \%$; Fig. $7 \mathrm{~b}$ ). These minerals result from primarily physical weathering of lower/ middle Palaeozoic rocks (Appalachian Mountains; Griffin et al., 1968; Potter et al., 1975). This distribution pattern agrees with previous observations in the same area (Pinsak and Murray, 1960; Weaver, 1967; Johnson and Kelley, 1984).

(Zone 3) The south-eastern United States region is typified by the relative abundance of kaolinite, often exceeding 40\% (Fig. 7a). The erosion of Neogene marine terraces along the Georgia coast, which is covered by red-yellow podzolic soils, derived from the Appalachian Mountain saprolites (Fig. 5), yields kaolinite-rich sediments (Pirkle,1960). The reflectance data of Balsam and Beeson (2003) support the hypothesis that Georgia is one of the main sources of kaolinite delivered to the Gulf of Mexico. The abundance of kaolinite in this province reflects mostly the composition of polygenetic palaeosoils, although produced at a lower rate today.

(Zone 4) The last province covers the south-western Mississippi River- and the Brazos River watersheds (Fig. 9). River clay loads from this area are mainly composed of illite ( $>50 \%$; Fig. 6b) and kaolinite ( $>25 \%$; Fig. 7a). High values of illite in this area are explained by the proximity of Colorado Plateau where frost shattering and other mechanical erosion processes reactivate recurrently in wintertime. The Llano Estacado, which is in the middle of this area (Fig. 5), is uplifted plateau of Late Tertiary riverine illiteand kaolinite-rich sediments (Parry and Reeves, 1968; Glass et al., 1973; USGS Geological map). 


\section{River inputs into the Gulf of Mexico and oceanographic implications}

Three processes largely control the distribution of continentally derived clay minerals in the sediments of the Northern Gulf of Mexico.

\subsection{River inputs}

According to Pinsak and Murray (1960), the main factor controlling the marine distribution of clay minerals is the nature of the dominant particle sources. Our data show that the Northern Gulf of Mexico can be roughly divided into two separated provinces: a western smectite-rich $(>50 \%)$ and kaolinite-poor $(<20 \%)$ province and $(2)$ an eastern smectite-poor and kaolinite-rich province (Figs. 6a and 7a). This pattern clearly suggests that the clay mineral distribution in the Northern Gulf of Mexico is controlled by two main river systems.

The western smectite-rich province covers the main part of the Gulf of Mexico. This peculiar distribution reflects the prevailing detrital supply via the Mississippi River since the latter delivers the sediments to the Gulf of Mexico that are the most enriched in smectite (60$80 \%$ ). This is consistent with the fact that Mississippi River discharge is 20 times larger than all other rivers combined feeding the Gulf of Mexico (Griffin, 1962; Chamley and Kennett, 1976). As a consequence the fine-grained sedimentation in the Northern Gulf of Mexico is mainly controlled by the detrital inputs from the Mississippi River. Since the Mississippi River detrital supply is depleted in chlorite, the area directly under the influence of the Mississippi River inputs is characterized by chlorite-poor deposits ( $<4 \%$; Fig. $7 b)$.

The eastern kaolinite-rich province corresponds mainly to the Alabama-Florida shelf and the clay mineral assemblages probably signal a local origin. The Apalachicola River and the Mobile River system, which drain both the kaolinite-rich south-eastern continental province (Zone 3) and the chlorite-rich Appalachian Mountains (Zone 2; Fig. 9), likely account for the kaolinite- and chlorite-rich sediments onto this eastern province (Fig. 7).

297 Parker et al. (1992) noted indeed that the provenance of the clay-mineral suite observed in the Alabama shelf is primarily from the Mobile River system. Moreover, Mazzullo and Peterson, 1989 analysed the late Quaternary silts on the Northern Gulf of Mexico continental shelf and identified two provinces in the Alabama-Florida shelf which correspond to areas directly influenced by the Mobile River and Apalachicola River respectively. The coeval occurrence of high kaolinite and chlorite contents in surface sediments of the eastern province of the Gulf of Mexico is somehow surprising. Indeed, chlorite is early removed under the weathering conditions that prevail in Alabama, Florida and Cuba whereas kaolinite is likely to be more 
different source rivers (as reflected by different stages of weathering). Unfortunately we have not found data to support this hypothesis yet. Russell et al. (2000) noticed that chlorite is one alteration mineral in the Encrucijada Formation, of Albian-Cenomanian age, west of Havana. This chlorite may be currently (or have been over the recent past) transported to the Gulf of Mexico and may explain the high chlorite content in sediment off Cuba.

Balsam and Beeson (2003) delineated transport and dispersal paths for kaolinite based on the factor analysis of the first derivatives of the percent reflectance data from 186 core-top and grab samples distributed throughout the Gulf of Mexico. They proposed that kaolinite from the Mobile River system is transported across the shelf and into deeper portions of the Gulf. This is in agreement with our observations and may explain why sediments off Mobile Bay and of the Mississippi River Delta have slightly higher kaolinite content $(>12 \%)$ than sediments of the Louisiana continental slope (Fig. 7a).

The other northern Gulf-Coast Rivers (e.g. Atchafalaya, Brazos, and Rio Grande rivers) have more local influences. Atchafalaya Bay delivers illite-rich sediments to the Louisiana shelf. These sediments are further transported across the Louisiana slope and into the deep Gulf of Mexico (Fig. 6b). The Rio Grande and/or its tributary (the Pecos River) drain the illite- and kaolinite-rich continental province defined as Zone 4 (Fig. 9) and distribute illite-rich sediments $(>26 \%$ ) over the Texas continental shelf and slope (Fig. 6b). Similarly, the clay mineral fraction of sediments off the Rio Grande and into the deep-sea plain are richer in kaolinite than Louisiana continental slope deposits, in agreement with Balsam and Beeson (2003) results. However, the respective kaolinite concentration maps show some discrepancies. According to Balsam and Beeson results (2003), the maximum kaolinite concentration area is located in the deep-sea plain of the Gulf of Mexico. Kaolinite content is highest in sediments of the Alabama-Florida shelf in our distribution map, in agreement with the previous work of Griffin (1962). Moreover, the comparison of kaolinite distribution map on the continent with marine distribution map suggests a clear relationship between the major continental source of kaolinite and the kaolinite-rich Alabama-Florida shelves (Zone 3; Fig. 9).

\subsection{Differential settling}

A regular offshore decrease of illite contents off the main Northern Gulf-coast Rivers with an exception for the Atchafalaya Bay appears on the illite distribution map (Fig. 6b). Illite generally has the largest grain size distribution of the clay mineral fraction in the Mississippi River suspended sediment (Johnson and Kelley, 1984; their figure 2) and in loess. 
340 Even when illite floccules are smaller than those of smectite, they are denser (Sakamoto, 341 1972), and consequently, illite settles more rapidly than the other clay minerals. The observed 342 zoned pattern suggest that differential settling, with larger flocs and grain-size being 343 deposited nearest shore, is one of the processes affecting clay mineral distribution in the 344 Northern Gulf of Mexico. The distributions of various clay mineral peak-area ratios 345 (illite/smectite, illite/kaolinite, illite/chlorite [maps not shown]) over the Northern Gulf of 346 Mexico confirm the apparent decrease in abundance of illite towards the deeper basin. This 347 local differential settling of clay minerals has not been previously reported elsewhere in Gulf 348 of Mexico sediments (Pinsak and Murray, 1960; Griffin, 1962; Scafe and Kunze, 1971; Doyle 349 and Sparks, 1980).

\subsection{Oceanic processes}

In addition to river inputs and differential settling, oceanic currents may also affect the distribution of clay minerals in the Northern Gulf of Mexico sediments. The surface circulation over the Gulf of Mexico, especially along the coast is modulated seasonally by changes in primary wind patterns. The dominant hydrologic feature of the Gulf of Mexico is the clockwise Loop Current (Fig. 1). The Loop Current enters the Gulf through the Yucatan Channel, intrudes variably northward, sometimes as far as the Mississippi Delta, and exits through the Florida Straits. Anti-cyclonic rings (Loop Current Rings) separate from the Loop Current every 6-17 months and travel westward across the Gulf of Mexico (Ohlmann and Niiler, 2005). General circulation on the Louisiana- Texas shelf is dominated by a cyclonic gyre, resulting in a strong, westward, coastal current associated with a relatively weak eastward current along the shelf break.

These hydrological features most likely influence the marine clay mineral distribution patterns in the Gulf of Mexico (Figs. 6 and 7). The geographical extent of the two distinct clay mineral marine provinces (see Section 6.1) is indeed consistent with an anti-cyclonic transport in the north-eastern Gulf of Mexico driven in part by the Loop Current. For instance, an eastward transportation of Mississippi sediments enriched in smectite is apparent on the western Alabama shelf. Similarly, southward transportation of the Apalachicola River kaolinite-rich sedimentary load clearly occurs over the Florida shelf (Figs. 1, 6a and 7a).

In the western part of the Gulf of Mexico, the chlorite-poor Louisiana continental shelf deposits likely result from a westward transportation of the Mississippi River chlorite-poor sedimentary load due to the dominant oceanic currents that affect this area (Fig. 7b). This transport pattern is not clear in the smectite distribution map due to its lower resolution (i.e. 
higher range of values). Likewise, the illite-rich suspended sediments from the Rio Grande

375 River are transported eastward over the Texas continental slope under the influence of the prevailing eastward oceanic currents.

The overall distribution of clay mineral assemblages in the Gulf of Mexico is in agreement with previously proposed sediment dispersal paths in the area excepted for the Florida shelf (Balsam and Beeson, 2003; Ellwood et al., 2006).

\section{Conclusions}

Clay mineral distribution maps of the North American continent and over the Northern Gulf of Mexico were generated using clay mineral data from erodible/alluvial sediments on land and from marine surface sediments. The United States can be divided into four provinces representing the main clay mineral source areas for sediments exported toward the Gulf of Mexico. The north-western Mississippi River watershed is characterized by high smectite content which reflects both the composition of Cretaceous, Tertiary and Pleistocene bedrock associated with a bentonitic or authigenic origin. The Great Lakes area and the OhioTennessee River catchment areas deliver mainly illite and chlorite, due to the chiefly physical, as opposed to chemical, weathering and erosion of Palaeozoic rocks. The Brazos River and south-western Mississippi River watersheds are dominated by illite and kaolinite released by the erosion of the Colorado Plateau and the Llano Estacado. The south-eastern part of the United States constitutes a major kaolinitic province. This kaolinite is derived from inherited red yellow podzolic soils.

The comparison of clay distribution patterns of marine surface sediments with results obtained on the continent permits the identification of three main factors controlling claymineral distribution in the Gulf of Mexico. (1) Relative fluvial contribution is the most important factor controlling the clay mineral composition of marine sediments. The dominant source is the terrigenous supply via the Mississippi River as supported by the high smectite content over the Northern Gulf of Mexico, whereas the Mobile, Apalachicola, Atchafalaya, Rio Grande and Brazos Rivers inputs have more local influences. (2) Differential settling, suggested by the illite gradient from the coast to the deep sea off the main Gulf- Coast Rivers, is identified as a contributing factor controlling clay distribution locally in the Gulf of

404 Mexico. (3) Surface oceanic currents, controlled by either the Loop Current or seasonal winds, influence the distribution of clay minerals. We can identify a southward transport of the Mobile and Apalachicola kaolinite-rich sediments over the Florida shelf; a westward 
affecting the eastern part of the Louisiana shelf and an eastward transport of Rio Grande suspended sediments over the Texas slope. The distribution of the two clay mineral marine provinces (the western smectite-rich province and the eastern kaolinite-rich province) is indeed coherent with the anti-cyclonic north-eastern Gulf of Mexico circulation influenced by the Loop Current. This overview of the dominant factors controlling recent clay mineral distributions in the Gulf of Mexico within the studied transect lays the groundwork for the use of clay-mineral assemblages for downcore investigations, particularly during the last glacial cycle when clay mineral fluvial inputs have likely been different from those of today due to the presence of the Laurentide Ice Sheet which modified the erosional pattern. The study of the clay mineral assemblages supplied to the Gulf of Mexico during meltwater pulses should,

418 for instance, provide valuable information on their provenance, and therefore contribute to documenting the climatic conditions over the North American continent during the last glacial period (Sionneau et al., in preparation).

\section{Acknowledgements}

The authors would like to thank Bruno Minguely for his assistance on the Surfer software. We gratefully acknowledge Yvon Balut, the Institut Polaire Français Paul-Emile Victor, the officers and crew of the Marion Dufresne and the IMAGES program for marine sediment core collection. This work was supported by the "Géosystèmes" Laboratory of the University of Lille 1 (France) and by the Lamont-Doherty Earth Observatory of Columbia University (USA). The authors thank William L. Balsam and an anonymous reviewer for their helpful

\section{References}

Aharon, P., 2003. Meltwater flooding events in the Gulf of Mexico revisited: Implications for rapid climate changes during the last deglaciation. Paleoceanography 18, 1079. doi:10.1029/2002PA000840.

Allen, B.L., Harris, B.L., Davis, K.R., Miller, G.B., 1972. The mineralogy and chemistry of high plains playa lake soils and sediments. Report WRC 72-4, Texas Tech. University, 75 pp. Balsam, W.L., Beeson, J.P., 2003. Sea-floor sediment distribution in the Gulf of Mexico. Deep-Sea Research 50, 1421-1444. 
layer of the abyssal Atlantic Ocean. Marine Geology 23, 155-172.

443 Biscaye, P.E., Grousset, F.E., Revel, M., Van der Gaast, S., Zielinski, G.A., Vaars, A., Kukla, 444 G., 1997. Asian provenance of glacial dust (stage 2) in the Greenland Ice Sheet Project 2 Ice 445 Core, Summit, Greenland. Journal of Geophysical Research 102, 26,765-26,781.

446 Bond, G.C., 1995. Climate and the conveyor. Nature 377, 383-384.

447 Boulay, S., Colin, C., Trentesaux, A., Frank, N., Liu, Z., 2005. Sediment sources and East 448 Asian monsoon intensity over the last $450 \mathrm{ky}$. Mineralogical and geochemical investigations 449 on South China Sea sediments. Paleogeography, Paleoclimatology. Paleoecology 228, 260450277.

451 Bout-Roumazeilles, V., Trentesaux, T., 2006. Sedimentologic analysis of cores recovered 452 from the Marion Dufresne cruise in the Gulf of Mexico, 2-18 July 2002. In: Winters, W., 453 Lorenson, T.D., Paull, C.K. (Eds.), Initial Report of the IMAGES VIII/PAGE 127 Gas 454 Hydrate and Paleoclimate Cruise on the Marion Dufresne in the Gulf of Mexico, p. 29. 2-18 455 July 2002, US Geological Survey, Open-File Report 2004-1358.

456 Broecker, W.S., 1991. The great ocean conveyor. Oceanography 4, 79-89.

457 Broecker, W.S., Kennett, J.P., Flower, B.P., Teller, J.T., Trumbore, S., Bonani, G., Wolfli, 458 W., 1989. Routing of meltwater from the Laurentide Ice Sheet during the Younger Dryas cold 459 episode. Nature 341, 318-321.

460 Broecker, W.S., Bond, G., Klas, M., Bonani, G., Wolfli, W., 1990. A salt oscillator in the 461 glacial Atlantic? 1. The concept. Paleoceanography 5 (4), 469-477.

462 Brown, A.V., Brown, K.B., Jackson, D.C., Pierson, W.K., 2005. Lower Mississippi River and 463 its tributaries. In: Benke, A.C., Cushing, C.E. (Eds.), Rivers of North America. Elsevier 464 Academic Press, London, pp. 231-271.

465 Brown, G., Brindley, G.W., 1980. X-ray diffraction procedures for clay mineral 466 identification. In: Brindley, G.W., Brown, G. (Eds.), Crystal Structures of Clay Minerals and 467 their X-ray Identification. Mineralogical Society, London, pp. 305-359.

468 Brown, P.A., Kennett, J.P., 1998. Megaflood erosion and meltwater plumbing changes during 469 the last North American deglaciation recorded in Gulf of Mexico sediments. Geology 26, $470 \quad 599-602$.

471 Chamley, H., 1998. Clay mineral sedimentation in the ocean. In: Paquet, H., Clauer, N. 472 (Eds.), Soils and Sediments (Mineralogy and Geochemistry). Springer, Berlin, pp. 269-302.

473 Chamley, H., 1989. Clay Sedimentology. Springer, Berlin, 623 pp.

474 Chamley, H., Kennett, J.P., 1976. Argiles détritiques, Foraminifères planctoniques et 475 paléoclimats, dans des sédiments quaternaires du golfe du Mexique. C.R. Acad. Sci. Paris 
477 Clark, P.U., Marshall, S.J., Clarke, G.K.C., Hostetler, S.W., Licciardi, J.M., Teller, J.T., 2001. 478 Freshwater forcing of abrupt climate change during the last glaciation. Science 293, 283-287. 479 Clarke, G.K.C., Leverington, D.W., Teller, J.T., Dyke, A.S., 2003. Superlakes, megafloods, 480 and abrupt climate change. Science 301, 922-923.

481 Cummings, M.L., Scrivner, J.V., 1980. The saprolite at the precambrian-cambrian contact, 482 Irvine Park, Chippewa Falls, Wisconsin. Transactions of the Wisconsin Academy of Sciences. 483 Arts and Letters 68, 22-29.

484 Curtin, D., Selles, F., Steppuhn, H., 1998. Estimating calcium-magnesium selectivity in 485 smectitic soils from organic matter and texture. Soil Science Society of America Journal 62 486 (5), 1280-1285.

487 Dahm, C.N., Edwards, R.J., Gelwick, F.P., 2005. Gulf Coast Rivers of the southwestern 488 United States. In: Benke, A.C., Cushing, C.E. (Eds.), Rivers of North America. Elsevier 489 Academic Press, London, pp. 181-219.

490 Delong, M.D., 2005. Upper Mississippi River Basin. In: Benke, A.C., Cushing, C.E. (Eds.), 491 Rivers of North America. Elsevier Academic Press, London, pp. 327-362.

492 Doyle, L.J., Sparks, T.N., 1980. Sediments of the Mississippi, Alabama, and Florida 493 (MAFLA) Continental Shelf. Journal of Sedimentary Petrology 50, 905-916.

494 Ellwood, B.B., Balsam, W.L., Roberts, H.H., 2006. Gulf of Mexico sediment sources and 495 sediment transport trends from magnetic susceptibility measurements of surface samples. 496 Marine Geology 203, 237-248.

497 Fagel, N., Hillaire-Marcel, C., Robert, C., 1997. Changes in the Western Boundary 498 Undercurrent outflow since the Last Glacial Maximum, from smectite/illite ratios in deep 499 Labrador Sea sediments. Paleoceanography 12, 79-96.

500 Fan, S., Oey, L., Hamilton, P., 2004. Assimilation of drifter and satellite data in a model of 501 the Northeastern Gulf of Mexico. Continental Shelf Research 24, 1001-1013.

502 Flower, B.P., Hastings, D.W., Hill, H.W., Quinn, T.M., 2004. Phasing of deglacial warming 503 and Laurentide Ice Sheet meltwater in the Gulf of Mexico. Geology 32, 597-600.

504 Galat, D.L., Berry Jr., C.R., Peters, E.J., White, R.G., 2005. Missouri River Basin. In: Benke, 505 A.C., Cushing, C.E. (Eds.), Rivers of North America. Elsevier Academic Press, London 727506468.

507 Gallet, S., Jahn, B.M., Van Vliet Lanoe, B., Dia, A., Rossello, E., 1998. Loess geochemistry 508 and its implications for particle origin and composition of the upper continental crust. Earth 509 and Planetary Science Letters 156, 157-172. 
510 Gerrard, M., Caquineau, S., Pinheiro, J., Stoops, G., 2007. Weathering and allophone 511 neoformation in soils developed on volcanic ash in the Azores. European Journal of Soil 512 Science 58, 496-515.

513 Gingele, F.X., De Deckker, P., Hillenbrand, C.-D., 2001. Clay mineral distribution in surface 514 sediments between Indonesia and NW Australia source and transport by ocean currents. 515 Marine Geology 179, 135-146.

516 Glass, H.D., Frye, J.C., Leonard, A.B., 1973. Clay minerals in east-central New Mexico. New 517 Mexico Bureau of Geology and Mineral Resources. Circular 139, 14.

518 Gradusov, B.P., 1974. A tentative study of clay mineral distribution in soils of the world. 519 Geoderma 12, 49-55.

520 Griffin, G.M., 1962. Regional clay mineral facies. Products of weathering intensity and 521 current distribution in the northeastern Gulf of Mexico. Geological Society

522 of America Bulletin 73, 737-768.

523 Griffin, J.J., Goldberg, E.D., 1969. Recent sediments of Caribbean Sea. The American 524 Association of Petroleum Geologists 11, 258-268.

525 Griffin, J.J., Windom, H., Goldberg, E.D., 1968. The distribution of clay minerals in the 526 World Ocean. Deep-Sea Research 15, 433-459.

527 Haug, G.H., Tiedemann, R., 1998. Effect of the formation of the Isthmus of Panama on 528 Atlantic Ocean thermohaline circulation. Nature 393, 673-676.

529 Holtzapffel, T., 1985. Les minéraux argileux: Préparation, Analyse Diffractométrique et 530 Détermination. Société Géologique du Nord, Villeneuve d'Ascq, 136 pp.

531 Huertas, F.J., Fiore, S., Huertas, F., Linares, J., 1999. Experimental study of the hydrothermal 532 formation of kaolinite. Chemical Geology 156, 171-190.

533 Irving, R.D., 1876. On Kaolin in Wisconsin. Wisconsin Academy of Science Arts and Letters 534 Transactions 3, 3-30.

535 Johnson, A.G., Kelley, J.T., 1984. Temporal, spatial, and textural variation in the mineralogy 536 of Mississippi River suspended sediment. Journal of Sedimentary Petrology 54, 67-72.

537 Jones, G.A., 1984. Advective transport of clay minerals in the region of the Rio Grande Rise. 538 Marine Geology 58, 187-212.

539 Joyce, J.E., Tjalsma, L.R.C., Prutzman, J.M., 1993. North American glacial meltwater history 540 for the past 2.3 m.y.: Oxygen isotope evidence from the Gulf of Mexico. Geology 21, 483541486.

542 Karpoff, A.M., Lagabrielle, Y., Boillot, G., Girardeau, J., 1989. L'authigenèse océanique de 543 palygorskite par halmyrolyse de péridotites serpentinisées (marge de Galice); ses implications 
544 géodynamiques. Comptes Rendus de l'Académie des Sciences, Série 2, Mécanique, Physique,

545 Chimie, Sciences de l'Univers. Sciences de la Terre 308, 647-654.

546 Kennett, J.P., Shackleton, N.J., 1975. Laurentide Ice Sheet Meltwater Recorded in Gulf of 547 Mexico Deep-Sea Cores. Science 188, 147-150.

548 Kraus, M.J., 1999. Paleosols in clastic sedimentary rocks: their geologic applications. Earth 549 Science Reviews 47, 41-70.

550 Laj, C., Labeyrie, L., Kissel, C., 2004. Le rapport de campagne à la mer MD 132/ PICASSO 551 IMAGES XI à bord du Marion Dufresne. OCE/2004/02.

552 Leventer, A., Williams, D.F., Kennett, J.P., 1982. Dynamics of the Laurentide ice sheet 553 during the last deglaciation: evidence from the Gulf of Mexico. Earth and Planetary Science 554 Letters 59, 11-17.

555 Manabe, S., Stouffer, R.J., 1997. Coupled ocean-atmosphere model response to freshwater 556 input: Comparison to Younger Dryas event. Paleoceanography 12, 321-336.

557 Matthews, W.J., Vaughn, C.C., Gido, K.B., Marsh-Matthews, E., 2005. Southern Plains 558 Rivers. In: Benke, A.C., Cushing, C.E. (Eds.), Rivers of North America. Elsevier Academic 559 Press, London, pp. 283-314.

560 Mazzullo, J., Peterson, M., 1989. Sources and dispersal of late Quaternary silt on the northern 561 Gulf of Mexico continental shelf. Marine Geology 86, 15-26.

562 Murray, H.H., Leininger, R.K., 1956. The effect of weathering on clay minerals. Clays Clay 563 Minerals. Proceedings of the National Conference on Clays and Clay Minerals 4, 340-347.

564 Ohlmann, J.C., Niiler, P.P., 2005. Circulation over the continental shelf in the northern Gulf 565 of Mexico. Progress in Oceanography 64, 45-81.

566 Parker, S.J., Shultz, A.W., Schroeder, W.W., 1992. Sediment characteristics and seafloor 567 topography of a palimpsest shelf, Mississippi-Alabama continental shelf. Quaternary Coasts 568 of the United States: Marine and Lacustrine Systems SEPM Special Publication, no. 48, ISBN 569 0-918985-98-6.

570 Parry, W.T., Reeves, C.C., 1968. Clay mineralogy of pluvial lake sediments, southern High 571 Plains, Texas. Journal of Sedimentary Research 38, 516-529.

572 Petschick, R. 2000. MacDiff 4.2 Manual. MacDiff [Online]. Available from: <http:// 573 www.geologie.uni-frankfurt.de/Staff/Homepages/Petschick/RainerE.html>. (Revised 2001574 05-17)

575 Petschick, R., Kuhn, G., Gingele, F., 1996. Clay mineral distribution in surface sediments of 576 the South Atlantic: sources, transport, and relation to oceanography. Marine Geology 130, $577 \quad 203-229$. 
578 Pinsak, A.P., Murray, H.H., 1960. Regional clay mineral patterns in the Gulf of Mexico.

579 Clays and Clay Minerals, 7th National Conference, Pergamon, Oxford, New York, pp. 162580177.

581 Pirkle, E.C., 1960. Kaolinitic sediments in peninsular Florida and origin of the kaolin. 582 Economic Geology 55, 1382-1405.

583 Potter, P.E., Heling, D., Shimp, N.E., van Wie, W., 1975. Clay mineralogy of modern alluvial 584 muds of the Mississippi River Basin. Bulletin du Centre Recherche Pau- SNPA 9, 353-389.

585 Pye, K., Johnson, R., 1988. Stratigraphy, geochemistry, and thermoluminescence ages of 586 lower. Mississippi Valley loess Earth Surface Processes and Landforms 13 (2), 103-124.

587 Rahmstorf, S., 1995. Bifurcations of the Atlantic thermohaline circulation in response to 588 changes in the hydrological cycle. Nature 378, 145-149.

589 Rateev, M.A., Gorbunova, Z.N., Lisitzin, A.P., Nosov, G.I., 1969. The distribution of clay 590 minerals in the oceans. Sedimentology 13, 21-43.

591 Russell, N., Moreira, J., Sanchez, R., 2000. Volcanogenic massive sulphide deposits of Cuba. 592 VMS deposits of Latin America. Geological Association of Canada, 241-258, Mineral 593 Deposits Division, Special Publications, no. 2 pp.

594 Sakamoto, W., 1972. Study on the process of river suspension from flocculation to 595 accumulation in estuary. Bulletin of Ocean Research Institute, University of Tokyo 5, 1-49.

596 Scafe, D.W., Kunze, G.W., 1971. A clay mineral investigation of six cores from the Gulf of 597 Mexico. Marine Geology 10, 69-85.

598 Schmitz,W.J. Jr., 2003. On the Circulation In and Around the Gulf of Mexico. Volume I: A 599 Review of the Deep Water Circulation. Available from: <http://www.serf. 600 tamus.edu/gomcirculation/>. (Revised 2005-10-26)

601 Smith, L.M., 2003. Playas of the Great Plains. University of Texas Press, 275 pp.

602 Smith, S.R., Jacobs, G.A., 2005. Seasonal circulation fields in the northern Gulf of Mexico 603 calculated by assimilating current meter, shipboard ADCP, and drifter data simultaneously 604 with the shallow water equations. Continental Shelf Research 25, 157-183.

605 Teller, J.T., 1995. History and drainage of large ice-dammed lakes along the Laurentide Ice 606 Sheet. Quaternary International 28, 83-92.

607 Thiry, M., 2000. Paleoclimatic interpretation of clay minerals in marine deposits: an outlook 608 from the continental origin. Earth Science Review 49, 201-221.

609 Thiry, M., Simon-Coinçon, R., Schmitt, J.-M., 1999. Paléoaltérations kaoliniques: 610 signification climatique et signature dans la colonne sédimentaire. C.R. Acad. Sci. Earth \& 611 Planetary Sciences 329, 853-863. 
612 Vukovich, F.M., Crissman, B.W., 1986. Aspects of warm rings in the Gulf of Mexico. Journal 613 of Geophysical Research 91, 2645-2660.

614 Weaver, C.E., 1967. Variability of a river clay suite. Journal of Sedimentary Petrology 37, 615 971-974.

616 White, D., Johnston, K., Miller,M., 2005. Ohio River Basin. In: Benke, A.C., Cushing, C.E. 617 (Eds.), Rivers of North America. Elsevier Academic Press, London, pp. 375-412.

618 Windom, H.L., 1976. Lithogenous material in marine sediments. In: Riley, J.P., Chester, R. 619 (Eds.), Chemical Oceanography. Academic Press, New York, London, pp. 103-135. 


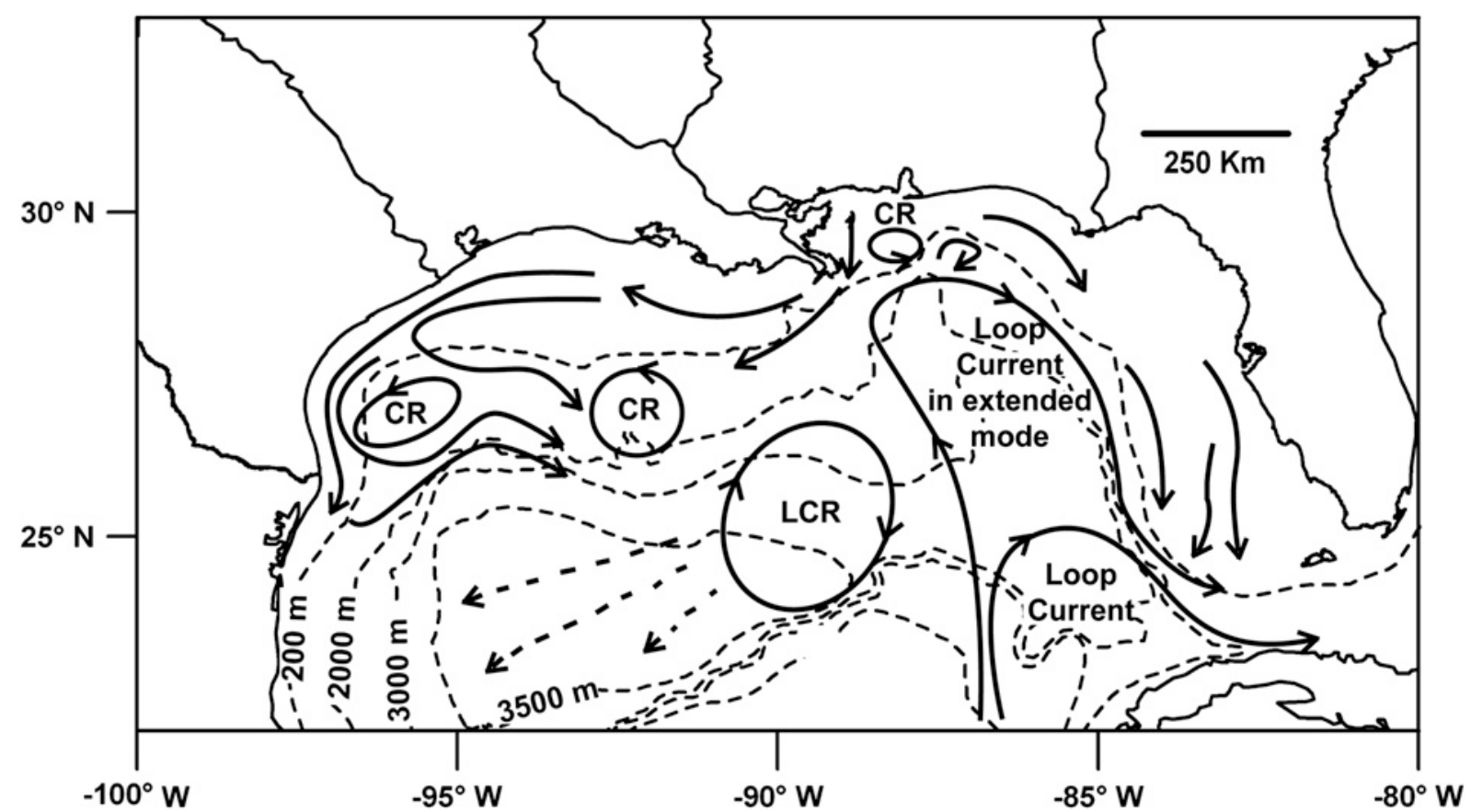

623 Fig. 1. Mean currents of the Gulf of Mexico (bold black arrows), including two different

624 states of the Loop Current, Loop Current Rings (LCR) and Cyclonic Rings (CR) (adapted 625 from Schmitz, 2003; Fan et al., 2004; Ohlmann and Niiler, 2005; Smith and Jacobs, 2005).

626 Dotted arrows represent propagation direction for LCR (Vukovich and Crissman, 1986). 


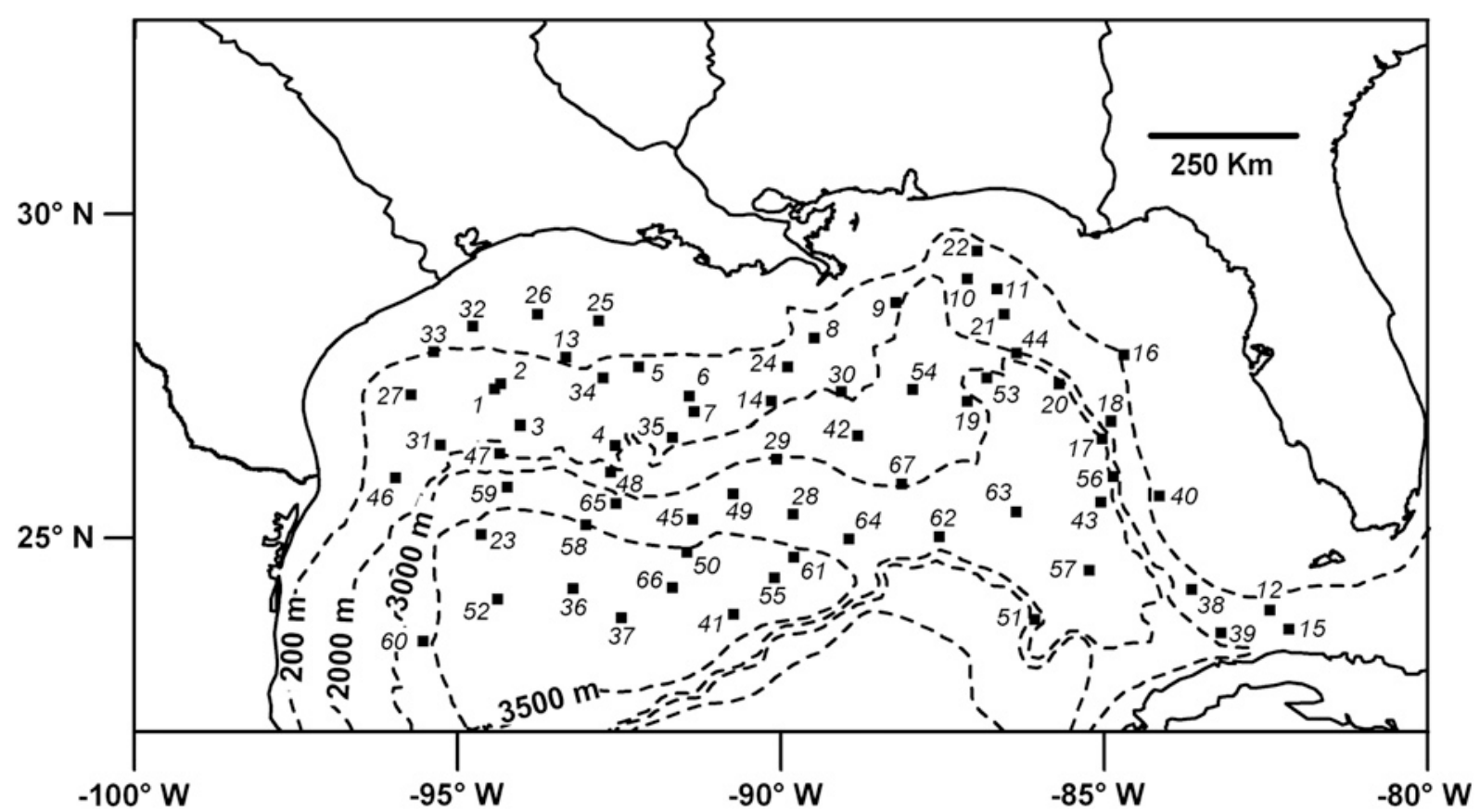

629 Fig. 2. Location of the 67 marine cores (1-67) recovered during RVs Robert Conrad, Vema, 630 Atlantis and Marion Dufresne cruises (RC, VM, AT and MD respectively in Table 1). 


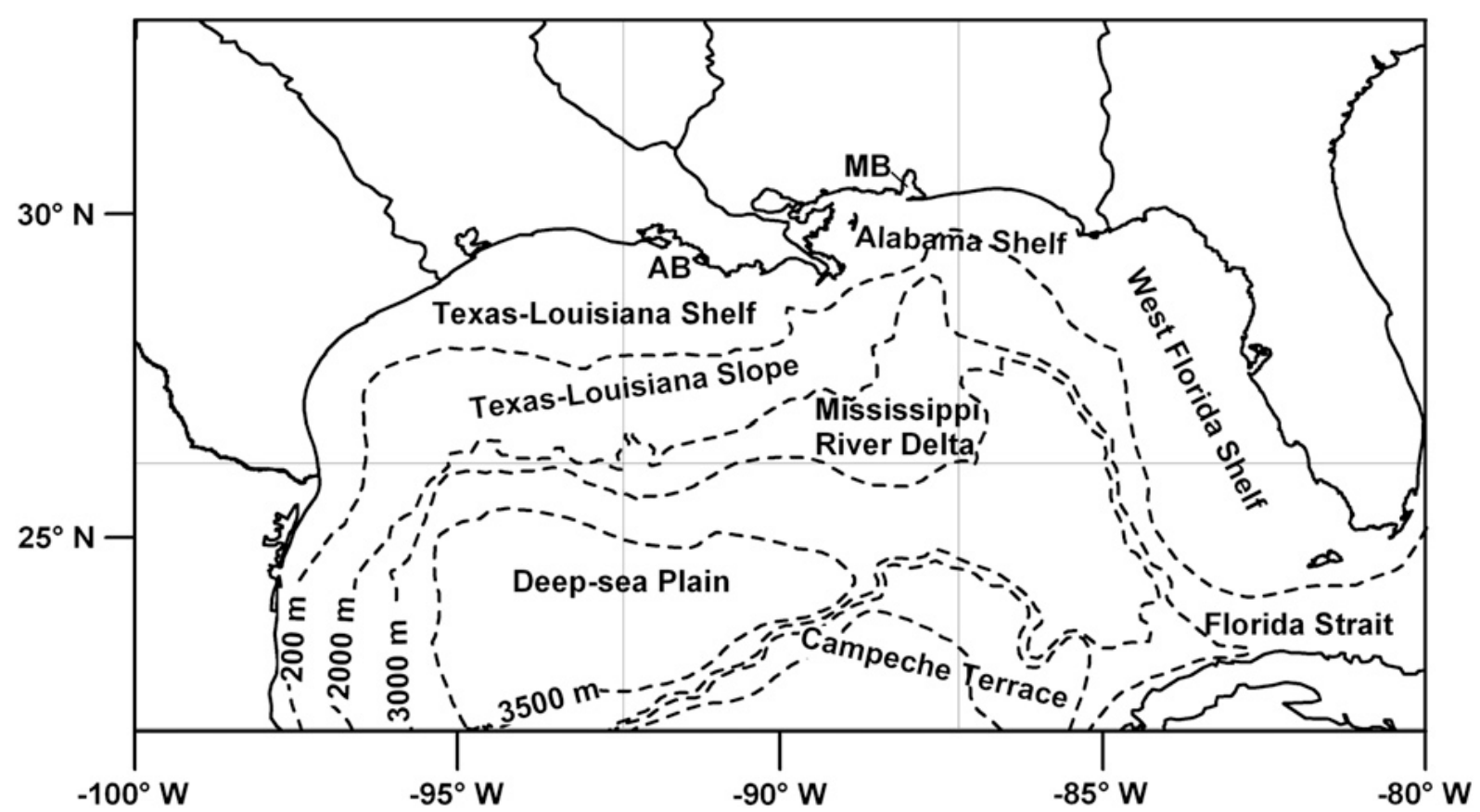

633 Fig. 3. Geomorphologic provinces of the Gulf of Mexico (AB: Atchafalaya Bay; MB: Mobile 634 Bay). 


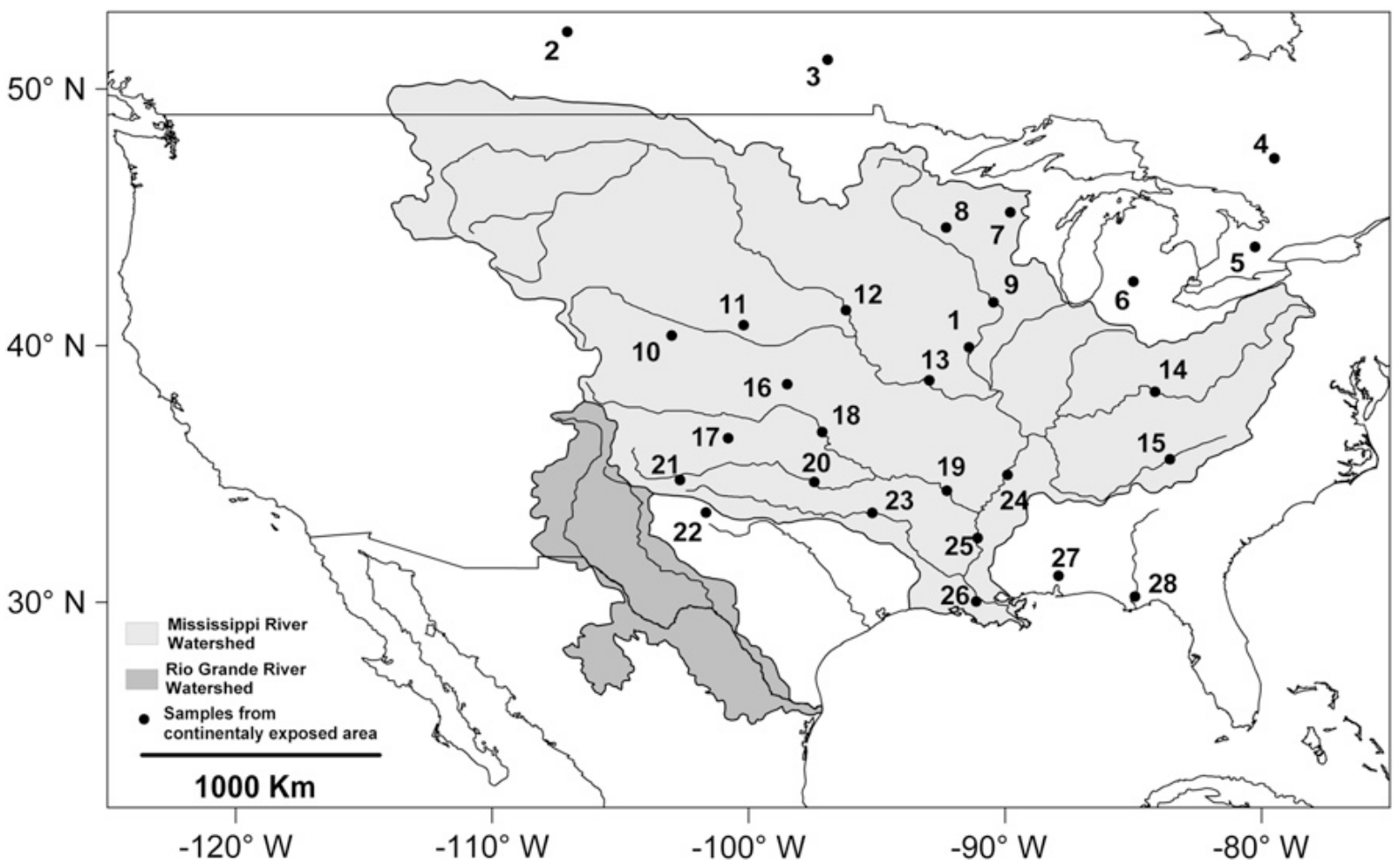

636 Fig. 4. Location of the 28 North American (1-28) sites used in the study. The extension of the

637 Mississippi River and Rio Grande River watersheds are respectively represented in light grey 638 and dark grey (Brown et al., 2005; Dahm et al., 2005; Delong, 2005; Galat et al., 2005; 639 Matthews et al., 2005; White et al., 2005). 


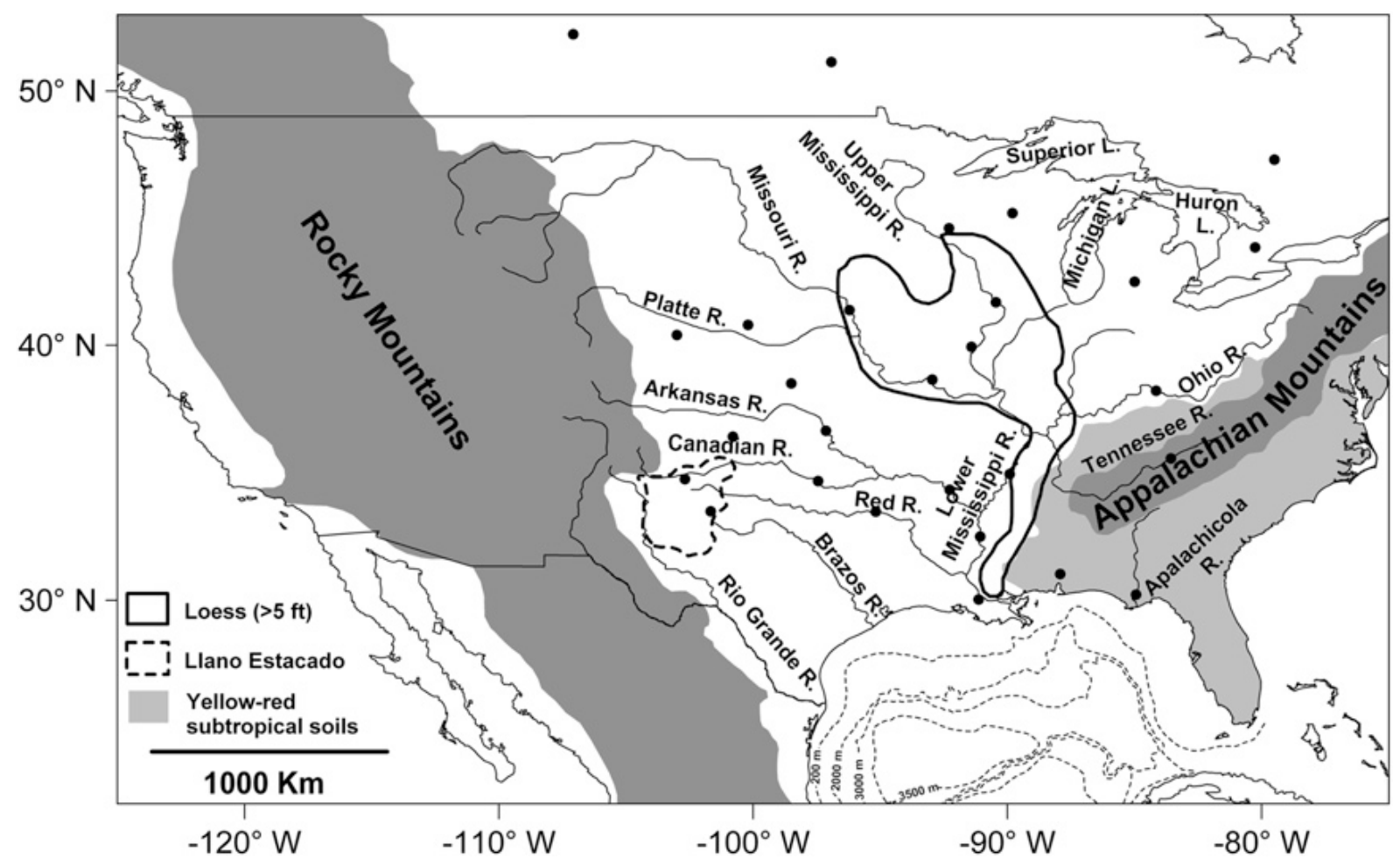

642 Fig. 5. Location of rivers and main geological provinces (loess province, yellow-red tropical 643 soils, Llano Estacado, Appalachians and Rocky Mountains). 


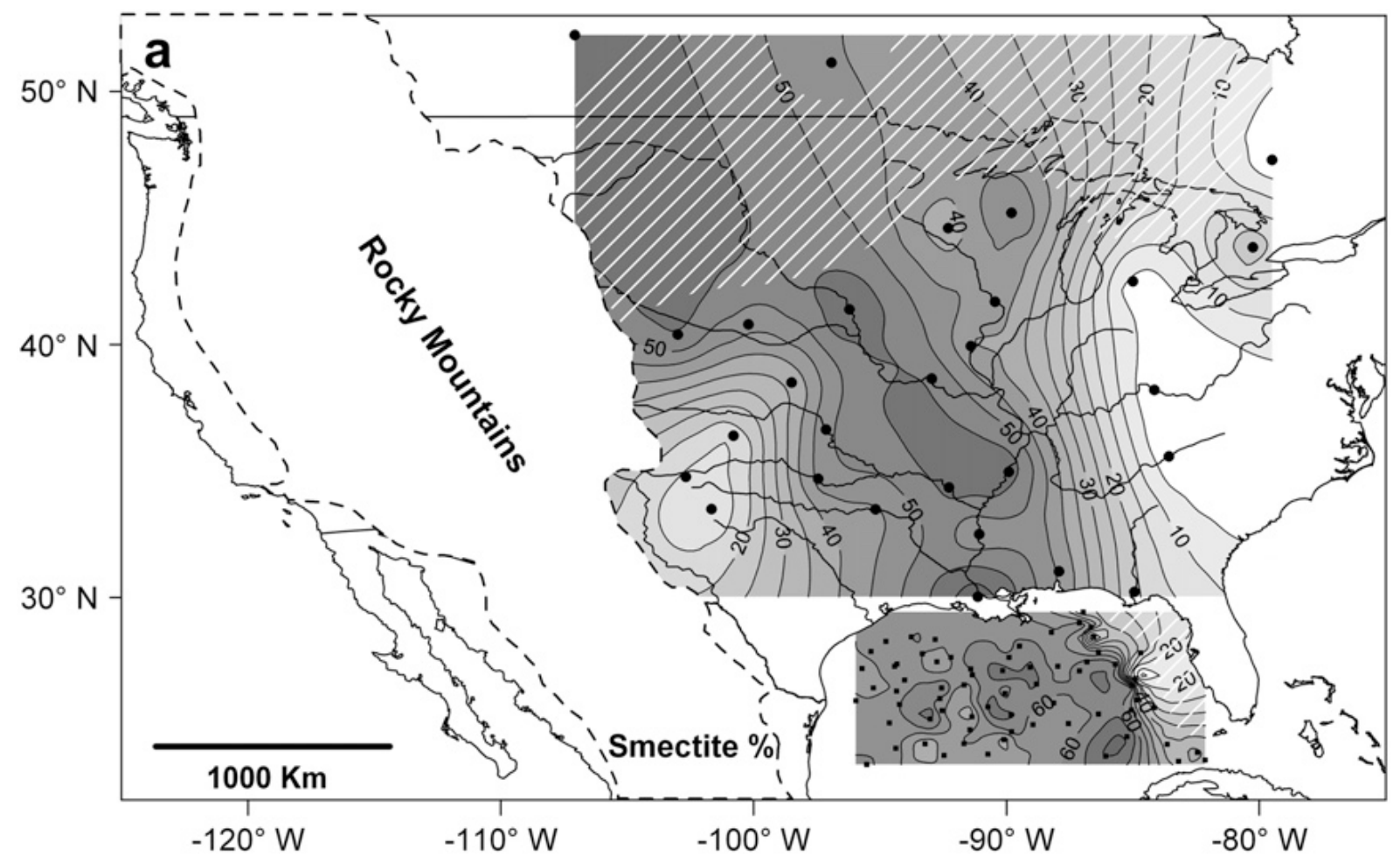

644

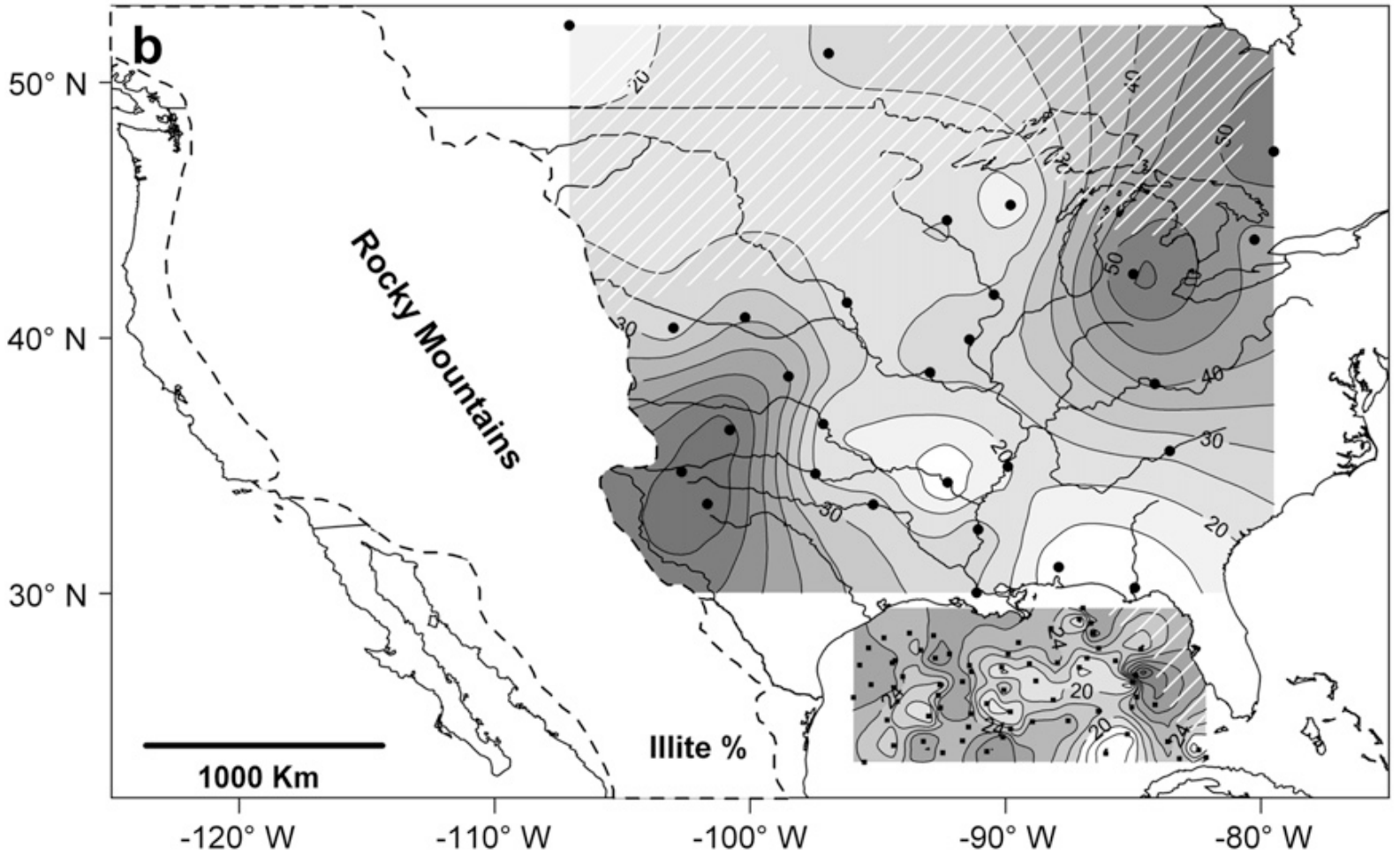

645 Fig. 6. Distribution of smectite (a) and illite (b) over the North American continent east of the 646 Rocky Mountains. White lines indicate areas with larger uncertainties. 

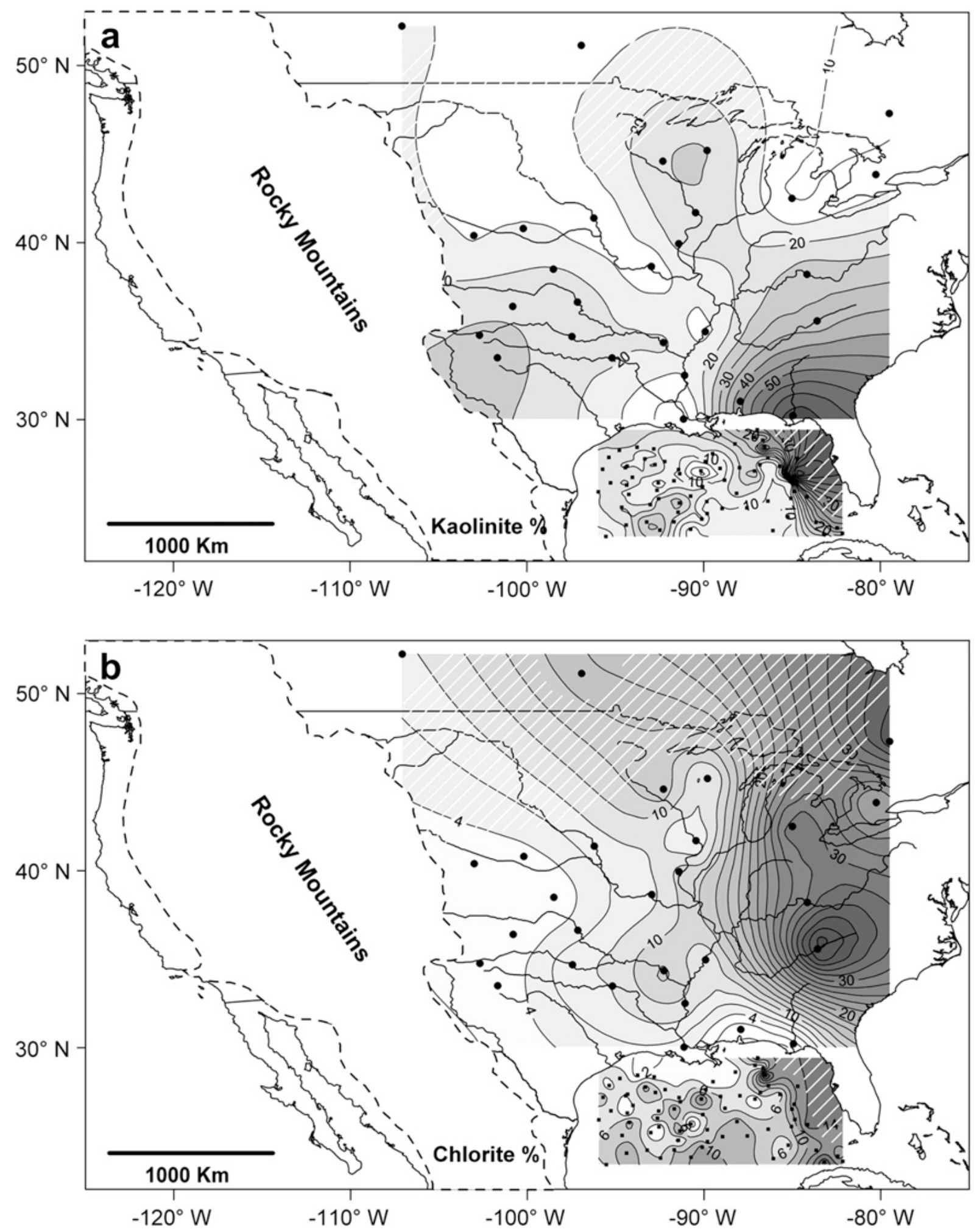

649 Fig. 7. Distribution of kaolinite (a) and chlorite (b) on the studied area. White lines indicate 650 areas with larger uncertainties. 


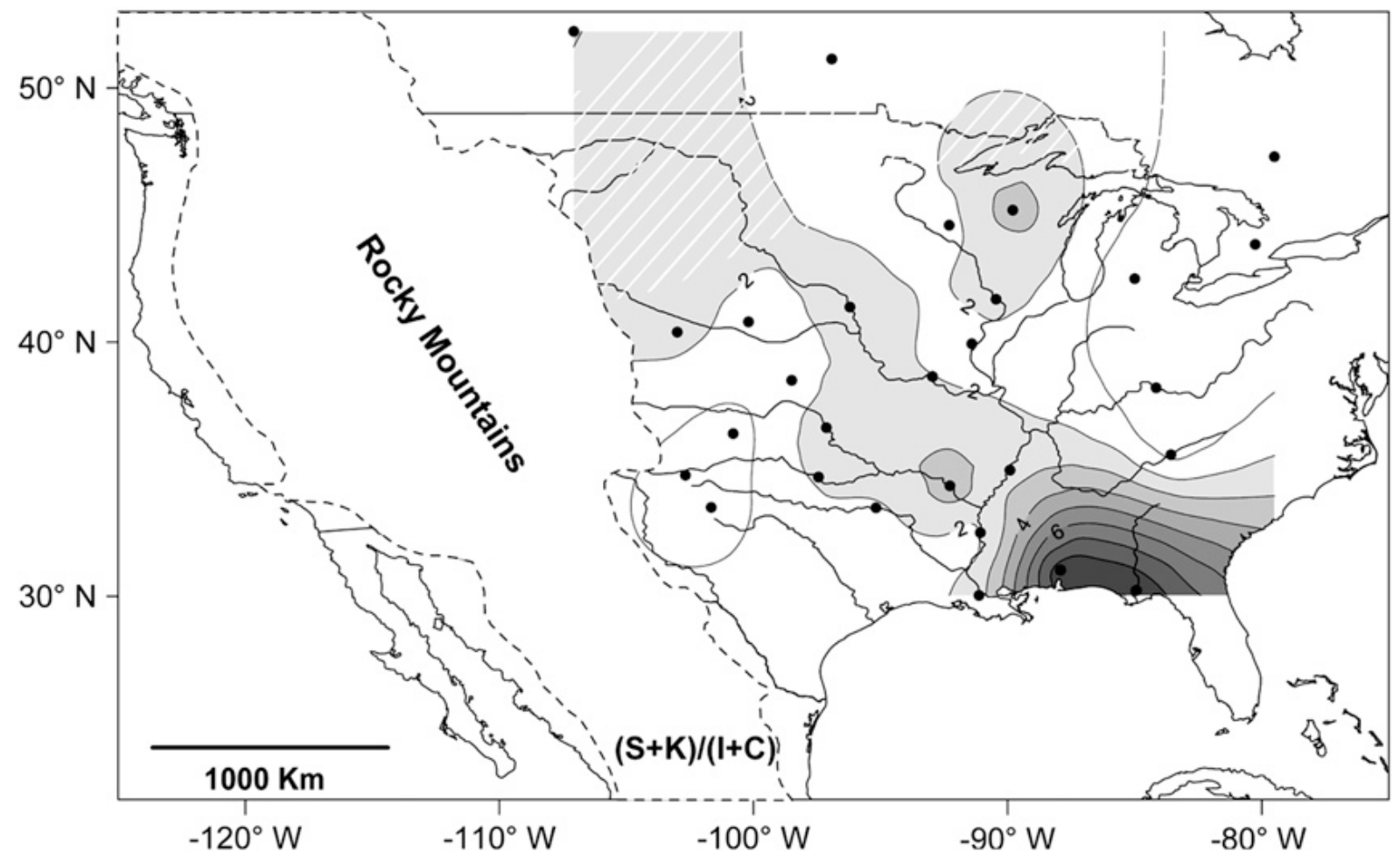

653 Fig. 8. Distribution of the (smectite + kaolinite)/(illite + chlorite) ratio which indicates the 654 type of weathering (chemical or physical) that affected the erodible sediments. High/low 655 values of this ratio suggest that chemical/physical weathering prevails in the studied region. 656 But the respective contributions of both physical and chemical weathering can not be easily 657 deduced in the areas characterized by intermediate values of the $(\mathrm{S}+\mathrm{K}) /(\mathrm{I}+\mathrm{C})$ ratio. For 658 instance, the values observed in Wisconsin (site 7) reflect the presence of kaolinite inherited 659 from old saprolite layers. In that case intermediate values of the $(S+K) /(I+C)$ ratio, cannot 660 be interpreted as a weathering index. White lines indicate areas with larger uncertainties. 


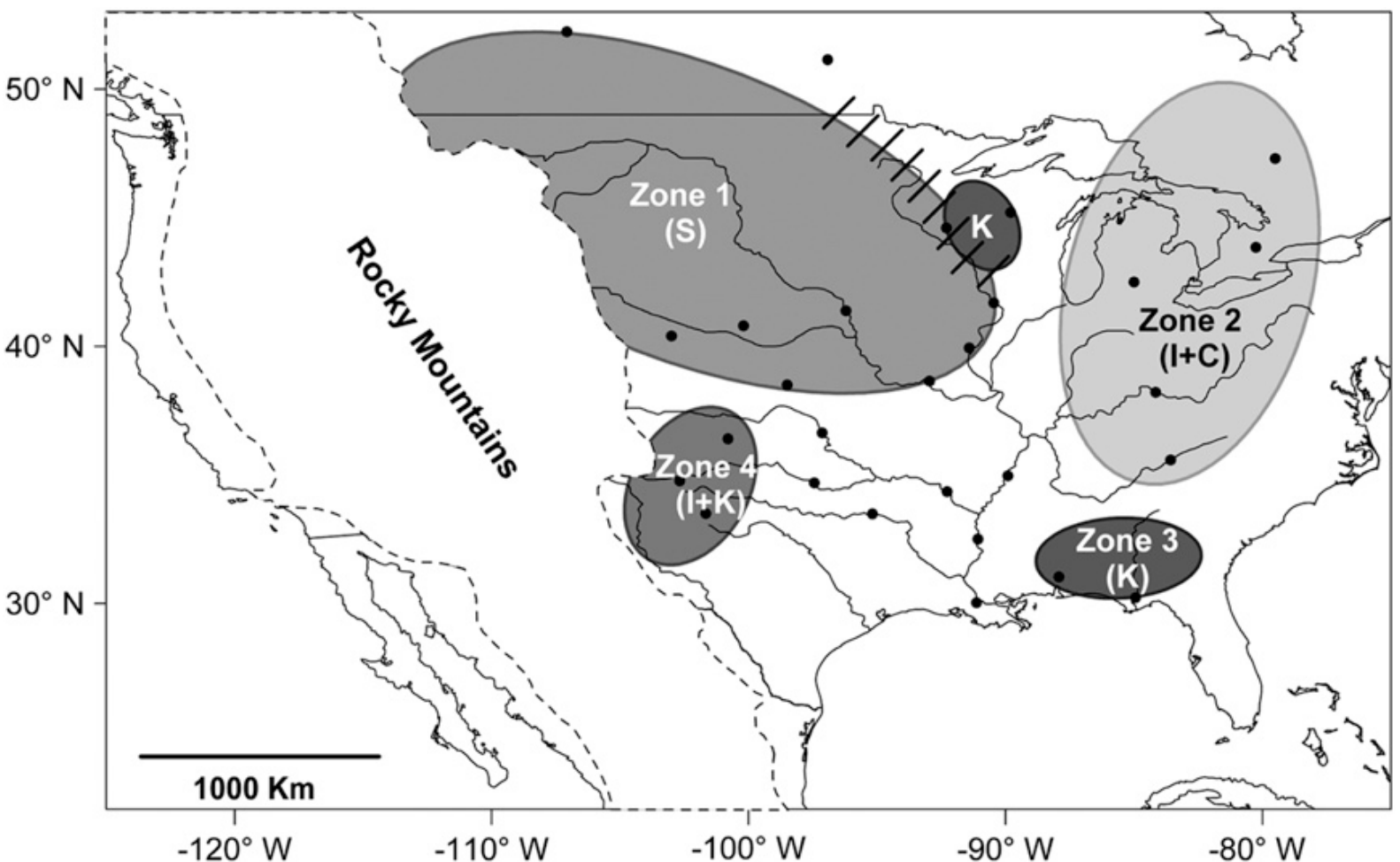

663 Fig. 9. Map of the four major clay mineral provinces over the United States. The smectite-rich 664 zone covers a kaolinite-rich area near the Great Lakes (Zone K). Black dashes along the 665 northern border of Zone 1 indicate uncertainty in the position of the boundary between this 666 zone and Zone K. 
669 Location, water depth and clay mineral composition of surface sediments from the northern 670 Gulf of Mexico

\begin{tabular}{|c|c|c|c|c|c|c|c|c|}
\hline Site & Core & Latitude & Longitude & Water (m) & Smectite ( $(x)$ & Illite (\%) & Kaolinite (\%) & Chlorite (x) \\
\hline$\overline{1}$ & MD03-2641 & $27.29^{\circ} \mathrm{N}$ & $-094.43^{\circ} \mathrm{W}$ & 1427 & 58 & 27 & 11 & 4 \\
\hline 2 & MD03-2643 & $2737^{\circ} \mathrm{N}$ & $-094.33^{\circ} \mathrm{W}$ & 1379 & 57 & 27 & 12 & 4 \\
\hline 3 & MD02-2533/2534 & $26.74^{\circ} \mathrm{N}$ & $-094.03^{\circ} \mathrm{W}$ & 1350 & 59 & 23 & 14 & 4 \\
\hline 4 & MD02-2549 & $26.43^{\circ} \mathrm{N}$ & $-092.57^{\circ} \mathrm{W}$ & 2049 & 67 & 20 & 9 & 4 \\
\hline 5 & MD02-2548 & $27.64^{\circ} \mathrm{N}$ & $-092.20^{\circ} \mathrm{W}$ & 610 & 57 & 28 & 10 & 5 \\
\hline 6 & MD02-2553 & $27.18^{\circ} \mathrm{N}$ & $-09142^{\circ} \mathrm{W}$ & 2259 & 62 & 23 & 11 & 4 \\
\hline 7 & MD02-2550/2552 & $26.95^{\circ} \mathrm{N}$ & $-09135^{\circ} \mathrm{W}$ & 2245 & 60 & 25 & 9 & 6 \\
\hline 8 & MD02-2558 & $28.08^{\circ} \mathrm{N}$ & $-089.49^{\circ} \mathrm{W}$ & 1125 & 62 & 25 & 11 & 2 \\
\hline 9 & MD02-2574 & $28,63^{\circ} \mathrm{N}$ & $-088.22^{\circ} \mathrm{W}$ & 1963 & 56 & 25 & 16 & 3 \\
\hline 10 & MD02-2575/2576 & $29.00^{\circ} \mathrm{N}$ & $-087.12^{\circ} \mathrm{W}$ & 848 & 60 & 16 & 19 & 5 \\
\hline 11 & MD02-2577/2578 & $28.84^{\circ} \mathrm{N}$ & $-086.66^{\circ} \mathrm{W}$ & 476 & 53 & 25 & 18 & 4 \\
\hline 12 & MD02-2581 & $23.88^{\circ} \mathrm{N}$ & $-082.44^{\circ} \mathrm{W}$ & 1063 & 49 & 14 & 26 & 11 \\
\hline 13 & AT185-43P & $27.78^{\circ} \mathrm{N}$ & $-093.33^{\circ} \mathrm{W}$ & 183 & 59 & 23 & 9 & 9 \\
\hline 14 & AT185-58P & $27.11^{\circ} \mathrm{N}$ & $-090.15^{\circ} \mathrm{W}$ & 2138 & 72 & 15 & 0 & 13 \\
\hline 15 & VM3-7P & $23.58^{\circ} \mathrm{N}$ & $-082.15^{\circ} \mathrm{W}$ & 1681 & 42 & 25 & 20 & 13 \\
\hline 16 & VM3-9P & $27.82^{\circ} \mathrm{N}$ & $-084.70^{\circ} \mathrm{W}$ & 181 & 34 & 19 & 34 & 13 \\
\hline 17 & VM3-16P & $26.53^{\circ} \mathrm{N}$ & $-085.03^{\circ} \mathrm{W}$ & 3286 & 62 & 15 & 13 & 10 \\
\hline 18 & VM3-19P & $26.80^{\circ} \mathrm{N}$ & $-084.90^{\circ} \mathrm{W}$ & 730 & 0 & 40 & 48 & 12 \\
\hline 19 & VM3-34P & $27.10^{\circ} \mathrm{N}$ & $-087.12^{\circ} \mathrm{W}$ & 2889 & 62 & 17 & 19 & 2 \\
\hline 20 & VM3-35P & $2737^{\circ} \mathrm{N}$ & $-085.70^{\circ} \mathrm{W}$ & 3221 & 64 & 20 & 11 & 5 \\
\hline 21 & VM3-39P & $28.45^{\circ} \mathrm{N}$ & $-086.55^{\circ} \mathrm{W}$ & 647 & 20 & 30 & 30 & 20 \\
\hline 22 & VM3-42P & $29.43^{\circ} \mathrm{N}$ & $-086.97^{\circ} \mathrm{W}$ & 667 & 32 & 28 & 27 & 13 \\
\hline 23 & VM3-68P & $25.05^{\circ} \mathrm{N}$ & $-094.63^{\circ} \mathrm{W}$ & 3630 & 55 & 23 & 15 & 7 \\
\hline 24 & VM3-81P & $27.63^{\circ} \mathrm{N}$ & $-089.90^{\circ} \mathrm{W}$ & 1123 & 57 & 26 & 12 & 5 \\
\hline 25 & VM3-83P & $28.35^{\circ} \mathrm{N}$ & $-092.82^{\circ} \mathrm{W}$ & 149 & 58 & 27 & 12 & 3 \\
\hline 26 & VM3-90P & $28.45^{\circ} \mathrm{N}$ & $-093.77^{\circ} \mathrm{W}$ & 140 & 61 & 24 & 14 & 1 \\
\hline 27 & VM3-93P & $27.20^{\circ} \mathrm{N}$ & $-095.72^{\circ} \mathrm{W}$ & 964 & 52 & 27 & 14 & 7 \\
\hline 28 & VM3-98P & $2537^{\circ} \mathrm{N}$ & $-089.82^{\circ} \mathrm{W}$ & 3424 & 67 & 17 & 9 & 7 \\
\hline 29 & VM3-99P & $26.22^{\circ} \mathrm{N}$ & $-090.07^{\circ} \mathrm{W}$ & 3157 & 54 & 26 & 14 & 6 \\
\hline 30 & VM3-100P & $27.25^{\circ} \mathrm{N}$ & $-089.07^{\circ} \mathrm{W}$ & 2034 & 67 & 20 & 7 & 6 \\
\hline 31 & VM3-121P & $26.43^{\circ} \mathrm{N}$ & $-095.27^{\circ} \mathrm{W}$ & 1648 & 54 & 28 & 13 & 5 \\
\hline 32 & VM3-108P & $28.27^{\circ} \mathrm{N}$ & $-094.77^{\circ} \mathrm{W}$ & 148 & 55 & 25 & 14 & 6 \\
\hline 33 & VM3-112P & $27.87^{\circ} \mathrm{N}$ & $-09537^{\circ} \mathrm{W}$ & 191 & 57 & 27 & 13 & 3 \\
\hline 34 & VM3-114P & $27.47^{\circ} \mathrm{N}$ & $-092.75^{\circ} \mathrm{W}$ & 761 & 44 & 32 & 17 & 7 \\
\hline 35 & VM3-118P & $26.55^{\circ} \mathrm{N}$ & $-09168^{\circ} \mathrm{W}$ & 2212 & 51 & 29 & 10 & 10 \\
\hline 36 & VM3-125P & $24.22^{\circ} \mathrm{N}$ & $-093.22^{\circ} \mathrm{W}$ & 3744 & 43 & 32 & 19 & 6 \\
\hline 37 & VM3-128P & $23.77^{\circ} \mathrm{N}$ & $-092.47^{\circ} \mathrm{W}$ & 3590 & 53 & 23 & 18 & 6 \\
\hline 38 & VM3-139P & $24.20^{\circ} \mathrm{N}$ & $-083.65^{\circ} \mathrm{W}$ & 1103 & 41 & 26 & 22 & 11 \\
\hline 39 & VM3-142P & $23.53^{\circ} \mathrm{N}$ & $-083.20^{\circ} \mathrm{W}$ & 1785 & 42 & 24 & 16 & 18 \\
\hline 40 & VM17-7P & $25.65^{\circ} \mathrm{N}$ & $-084.15^{\circ} \mathrm{W}$ & 154 & 30 & 30 & 25 & 15 \\
\hline 41 & VM17-19P & $23.82^{\circ} \mathrm{N}$ & $-090.73^{\circ} \mathrm{W}$ & 3706 & 54 & 30 & 6 & 10 \\
\hline 42 & VM18-362P & $26.58^{\circ} \mathrm{N}$ & $-088.82^{\circ} \mathrm{W}$ & 2577 & 67 & 17 & 11 & 5 \\
\hline 43 & $\mathrm{RC} 9-15 \mathrm{P}$ & $25.56^{\circ} \mathrm{N}$ & $-085.06^{\circ} \mathrm{W}$ & 3341 & 57 & 25 & 10 & 8 \\
\hline 44 & $\mathrm{RC9}-16 \mathrm{P}$ & $27.85^{\circ} \mathrm{N}$ & $-086.36^{\circ} \mathrm{W}$ & 3111 & 54 & 24 & 13 & 9 \\
\hline 45 & RC9-18P & $25.29^{\circ} \mathrm{N}$ & $-09137^{\circ} \mathrm{W}$ & 3374 & 43 & 28 & 18 & 11 \\
\hline 46 & $\mathrm{RC9}-21 \mathrm{P}$ & $25.93^{\circ} \mathrm{N}$ & $-095.96^{\circ} \mathrm{W}$ & 960 & 56 & 27 & 12 & 5 \\
\hline 47 & $\mathrm{RC} 9-22 \mathrm{P}$ & $26.31^{\circ} \mathrm{N}$ & $-094.35^{\circ} \mathrm{W}$ & 1955 & 55 & 28 & 15 & 2 \\
\hline 48 & $\mathrm{RC} 9-23 \mathrm{~T}$ & $26.02^{\circ} \mathrm{N}$ & $-092.63^{\circ} \mathrm{W}$ & 2111 & 58 & 25 & 9 & 8 \\
\hline 49 & $\mathrm{RC}-24 \mathrm{P}$ & $25.68^{\circ} \mathrm{N}$ & $-090.74^{\circ} \mathrm{W}$ & 3424 & 73 & 14 & 13 & 0 \\
\hline 50 & $\mathrm{RC} 9-25 \mathrm{P}$ & $24.78^{\circ} \mathrm{N}$ & $-091.45^{\circ} \mathrm{W}$ & 3576 & 58 & 24 & 15 & 3 \\
\hline 51 & $\mathrm{RC} 9-31 \mathrm{P}$ & $23.74^{\circ} \mathrm{N}$ & $-086.08^{\circ} \mathrm{W}$ & 3466 & 71 & 13 & 10 & 6 \\
\hline 52 & $\mathrm{RC} 10-267 \mathrm{P}$ & $24.05^{\circ} \mathrm{N}$ & $-09438^{\circ} \mathrm{W}$ & 3749 & 58 & 20 & 12 & 10 \\
\hline 53 & VM24-19P & $27,47^{\circ} \mathrm{N}$ & $-086.82^{\circ} \mathrm{W}$ & 3012 & 63 & 19 & 10 & 8 \\
\hline 54 & VM24-20P & $27.28^{\circ} \mathrm{N}$ & $-087.97^{\circ} \mathrm{W}$ & 2651 & 55 & 26 & 14 & 5 \\
\hline 55 & VM24-21P & $2438^{\circ} \mathrm{N}$ & $-090.10^{\circ} \mathrm{W}$ & 3654 & 46 & 30 & 13 & 11 \\
\hline 56 & $\mathrm{RC} 12-5 \mathrm{P}$ & $25.95^{\circ} \mathrm{N}$ & $-084.87^{\circ} \mathrm{W}$ & 2946 & 47 & 27 & 16 & 10 \\
\hline 57 & $\mathrm{RC} 12-4 \mathrm{P}$ & $24.50^{\circ} \mathrm{N}$ & $-085.23^{\circ} \mathrm{W}$ & 3405 & 72 & 15 & 8 & 5 \\
\hline 58 & $\mathrm{RC} 12-8 \mathrm{~T}$ & $25.20^{\circ} \mathrm{N}$ & $-093.02^{\circ} \mathrm{W}$ & 3576 & 71 & 15 & 11 & 3 \\
\hline 59 & $\mathrm{RC} 12-9 \mathrm{P}$ & $25.78^{\circ} \mathrm{N}$ & $-094.23^{\circ} \mathrm{W}$ & 3263 & 61 & 21 & 9 & 9 \\
\hline 60 & RC 10-10P & $23.40^{\circ} \mathrm{N}$ & $-095.53^{\circ} \mathrm{W}$ & 3054 & 61 & 24 & 9 & 6 \\
\hline 61 & $\mathrm{RC} 12-13 \mathrm{P}$ & $24.70^{\circ} \mathrm{N}$ & $-089.80^{\circ} \mathrm{W}$ & 3563 & 66 & 19 & 8 & 7 \\
\hline 62 & $\mathrm{RC} 12-14 \mathrm{P}$ & $25.02^{\circ} \mathrm{N}$ & $-087.55^{\circ} \mathrm{W}$ & 3389 & 56 & 26 & 9 & 9 \\
\hline 63 & VM26-131P & $25.40^{\circ} \mathrm{N}$ & $-086.37^{\circ} \mathrm{W}$ & 3252 & 60 & 23 & 10 & 7 \\
\hline 64 & VM26-132P & $24.98^{\circ} \mathrm{N}$ & $-088.95^{\circ} \mathrm{W}$ & 3484 & 56 & 25 & 10 & 9 \\
\hline 65 & VM26-138P & $25.53^{\circ} \mathrm{N}$ & $-092.55^{\circ} \mathrm{W}$ & 1677 & 55 & 28 & 15 & 2 \\
\hline 66 & VM26-141 P & $24.23^{\circ} \mathrm{N}$ & $-09168^{\circ} \mathrm{W}$ & 3740 & 54 & 25 & 13 & 8 \\
\hline 67 & VM26-142P & $25.83^{\circ} \mathrm{N}$ & $-088.13^{\circ} \mathrm{W}$ & 3103 & 59 & 19 & 13 & 9 \\
\hline
\end{tabular}


673 Table 2

674 Location, sediment type, number of samples $(\mathrm{N})$ and clay mineral composition of sites from

675 North America

\begin{tabular}{|c|c|c|c|c|c|c|c|c|c|}
\hline Site & Location & Latitude & Longitude & Type & Smectite ( $\mathscr{x})$ & Illite (x) & Kaolinite (*) & Chlorite (\%) & Reference \\
\hline 1 & Quincy, Illino is & $39.94^{\circ} \mathrm{N}$ & $-091,41^{\circ} \mathrm{W}$ & Loess & 39 & 27 & 22 & 11 & \\
\hline 2 & Saskatchewan & $52.23^{\circ} \mathrm{N}$ & $-107.07^{\circ} \mathrm{W}$ & River & 59 & 17 & 16 & 7 & \\
\hline 3 & Lake Manitoba & $51.14^{\circ} \mathrm{N}$ & $-096.92^{\circ} \mathrm{W}$ & Lake & 46 & 26 & 13 & 15 & \\
\hline 4 & Ottawa River & $47.30^{\circ} \mathrm{N}$ & $-079.50^{\circ} \mathrm{W}$ & River & 0 & 54 & 8 & 37 & \\
\hline 5 & Ontario & $43.85^{\circ} \mathrm{N}$ & $-080.26^{\circ} \mathrm{W}$ & Till & 25 & 43 & 12 & 20 & \\
\hline 6 & St. Francis Lake & $42.50^{\circ} \mathrm{N}$ & $-085.00^{\circ} \mathrm{W}$ & Till & 1 & 58 & 8 & 33 & \\
\hline 7 & Stetsonville & $45.20^{\circ} \mathrm{N}$ & $-089.80^{\circ} \mathrm{W}$ & Till & 53 & 15 & 26 & 7 & \\
\hline 8 & River Falls & $44.60^{\circ} \mathrm{N}$ & $-092.30^{\circ} \mathrm{W}$ & Loess & 35 & 26 & 25 & 14 & \\
\hline 9 & Upper Mississippi River & $41.69^{\circ} \mathrm{N}$ & $-090,46^{\circ} \mathrm{W}$ & & 45 & 25 & 25 & 5 & Potter et al_, 1975 \\
\hline 10 & Kelly section & $40.40^{\circ} \mathrm{N}$ & $-103.00^{\circ} \mathrm{W}$ & Loess & 57 & 26 & 14 & 3 & \\
\hline 11 & Bignell Hill/Eustis sections & $40.80^{\circ} \mathrm{N}$ & $-100.20^{\circ} \mathrm{W}$ & Loess & 47 & 34 & 16 & 3 & \\
\hline 12 & Upper Missouri River & $41.38^{\circ} \mathrm{N}$ & $-096.21^{\circ} \mathrm{W}$ & & 60 & 22 & 11 & 7 & Potter et al_, 1975 \\
\hline 13 & Lower Missouri River & $38.65^{\circ} \mathrm{N}$ & $-092.96^{\circ} \mathrm{W}$ & & 55 & 27 & 11 & 7 & Potter et al_, 1975 \\
\hline 14 & Ohio River & $38.21^{\circ} \mathrm{N}$ & $-084.16^{\circ} \mathrm{W}$ & & 0 & 41 & 29 & 30 & Potter et al_, 1975 \\
\hline 15 & Tennessee River & $35.58^{\circ} \mathrm{N}$ & $-083.57^{\circ} \mathrm{W}$ & & 0 & 26 & 31 & 43 & Potter et al_, 1975 \\
\hline 16 & Barton section & $38.50^{\circ} \mathrm{N}$ & $-098.50^{\circ} \mathrm{W}$ & Loess & 35 & 43 & 21 & 2 & \\
\hline 17 & Texas (Norwood House) & $36.40^{\circ} \mathrm{N}$ & $-100.80^{\circ} \mathrm{W}$ & Dust & 14 & 59 & 24 & 2 & \\
\hline 18 & Arkansas River & $36.64^{\circ} \mathrm{N}$ & $-097.14^{\circ} \mathrm{W}$ & & 50 & 21 & 24 & 5 & Potter et al_, 1975 \\
\hline 19 & Lower Arkansas River & $34.35^{\circ} \mathrm{N}$ & $-092.27^{\circ} \mathrm{W}$ & & 57 & 8 & 22 & 13 & Potter et al_, 1975 \\
\hline 20 & Canadian River & $34.69^{\circ} \mathrm{N}$ & $-097.45^{\circ} \mathrm{W}$ & & 48 & 23 & 21 & 8 & Potter et al_, 1975 \\
\hline 21 & Texas (Hereford) & $34.77^{\circ} \mathrm{N}$ & $-102.68^{\circ} \mathrm{W}$ & Dust & 14 & 56 & 26 & 4 & \\
\hline 22 & Texas (Lub bock) & $33.50^{\circ} \mathrm{N}$ & $-101.67^{\circ} \mathrm{W}$ & Dust & 9 & 60 & 28 & 3 & \\
\hline 23 & Red River & $33,49^{\circ} \mathrm{N}$ & $-095.78^{\circ} \mathrm{W}$ & & 43 & 28 & 21 & 8 & Potter et al_, 1975 \\
\hline 24 & Middle Mississippi River & $34.96^{\circ} \mathrm{N}$ & $-089.91^{\circ} \mathrm{W}$ & & 60 & 20 & 12 & 8 & Potter et al_, 1975 \\
\hline 25 & Mississippi River & $32.50^{\circ} \mathrm{N}$ & $-091.07^{\circ} \mathrm{W}$ & & 45 & 30 & 15 & 10 & Potter et al_, 1975 \\
\hline 26 & Lower Mississippi River & $30.04^{\circ} \mathrm{N}$ & $-091.3^{\circ} \mathrm{W}$ & & $65(60-80)$ & $25(20-30)$ & 5 (+chlorite: $10-20$ ) & 5 (minor) & Griffin, 1962 \\
\hline 27 & Mobile Bay & $31.03^{\circ} \mathrm{N}$ & $-087.92^{\circ} \mathrm{W}$ & & $45(40-50)$ & $10(0-10)$ & $45(40-50)$ & 0 (trace) & Griffin, 1962 \\
\hline 28 & Apalachicola River & $30.23^{\circ} \mathrm{N}$ & $-084.94^{\circ} \mathrm{W}$ & & $20(0-20)$ & $10(0-10)$ & $70(60-80)$ & 0 (trace) & Griffin, 1962 \\
\hline
\end{tabular}

